\title{
3 Research Square

\section{Public health vulnerability due to the exposure of dissolved metal(oid)s in tap water from a mega city (Dhaka, Bangladesh)}

Shabiha Hossain

BUP: Bangladesh University of Professionals

Amit Hasan Anik

BUP: Bangladesh University of Professionals

Rahat Khan ( $\square$ rahatkhan.baec@gmail.com )

Bangladesh Atomic Energy Commission https://orcid.org/0000-0002-5693-3892

Farah Tasneem Ahmed

BAEC: Bangladesh Atomic Energy Commission

Md. Abu Bakar Siddique

BCSIR: Bangladesh Council of Scientific and Industrial Research

Abdul Hadi Al Nafi Khan

BAEC: Bangladesh Atomic Energy Commission

Narottam Saha

The University of Queensland - Saint Lucia Campus: The University of Queensland

Abubakr M. Idris

King Khalid University

Mahbub Alam

BUP: Bangladesh University of Professionals

\section{Research Article}

Keywords: Tap-water, Dhaka city, Bangladesh, Dissolved potentially toxic elements, Water quality appraisement, Health risks estimation

Posted Date: August 30th, 2021

DOI: https://doi.org/10.21203/rs.3.rs-849871/v1

License: (c) (i) This work is licensed under a Creative Commons Attribution 4.0 International License.

Read Full License 


\section{Public health vulnerability due to the exposure of dissolved metal(oid)s in tap \\ 2 water from a mega city (Dhaka, Bangladesh)}

3

4 Shabiha Hossain ${ }^{\mathrm{a}, \mathrm{b}}$, Amit Hasan Anik ${ }^{\mathrm{a}, \mathrm{b}}$, Rahat Khan ${ }^{\mathrm{a}, *}$, Farah Tasneem Ahmed ${ }^{\mathrm{a}}$, Md. Abu Bakar

5 Siddique $^{\mathrm{c}}$, Abdul Hadi Al Nafi Khan ${ }^{\mathrm{a}}$, Narottam Saha ${ }^{\mathrm{d}}$, Abubakr M. Idris $^{\mathrm{e}, \mathrm{f}}$, Mahbub Alam $^{\mathrm{b}}$ 6

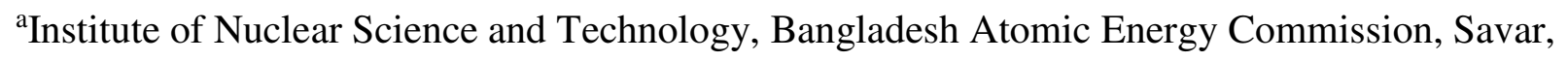
Dhaka-1349, Bangladesh

${ }^{\mathrm{b}}$ Department of Environmental Science, Bangladesh University of Professionals (BUP), Mirpur12, Cantonment, Dhaka-1216, Bangladesh

${ }^{\mathrm{c}}$ Institute of National Analytical Research and Service (INARS), Bangladesh Council of Scientific and Industrial Research (BCSIR), Dhanmondi, Dhaka-1205, Bangladesh

${ }^{\mathrm{d} S u s t a i n a b l e ~ M i n e r a l s ~ I n s t i t u t e, ~ C e n t e r ~ f o r ~ M i n e d ~ L a n d ~ R e h a b i l i t a t i o n, ~ T h e ~ U n i v e r s i t y ~ o f ~}$ Queensland, St Lucia QLD 4072, Australia

${ }^{\text {e}}$ Department of Chemistry, College of Science, King Khalid University, Abha, Saudi Arabia ${ }^{\mathrm{f}}$ Research Center for Advanced Materials Science (RCAMS), King Khalid University, Abha, Saudi Arabia

*Corresponding author: Rahat Khan (rahatkhan.baec@ gamil.com; https://orcid.org/0000-00025693-3892)

\section{Abstract}

Tap water is the sole source of water in urban cities but gradually being polluted by potentially toxic elements due to unplanned urbanization. The south Asian megacity, Dhaka (capital of Bangladesh) encounters drastic water pollution resulting mainly from anthropogenic differential factors. Consumption of such polluted water distributed to residents by pipelines can trigger health risks. Therefore, this study investigated the public health vulnerability associated with dissolved metal(oid)s in tap water collected across Dhaka city. The concentrations of $\mathrm{Cr}, \mathrm{Mn}$, $\mathrm{Fe}, \mathrm{Co}, \mathrm{Ni}, \mathrm{Cu}, \mathrm{Zn}, \mathrm{As}, \mathrm{Cd}, \mathrm{Hg}$ and $\mathrm{Pb}$ in measured tap water ranged from 8-156, 7-73, 400-20100, 
12-110, 7-101, 12-136, 12-908, 0.03-9.75, 1-5, 0.22-1.30, and 8-118 $\mu \mathrm{g} / \mathrm{L}$, respectively. Among the observed elements, $\mathrm{Pb}, \mathrm{Cr}$, and $\mathrm{Fe}$ concentrations in $18 \%, 26 \%$, and $75 \%$ of sampling sites, respectively, exceeded the standard guideline criteria of Bangladesh. Entropy-based water quality index demonstrated that $\sim 12 \%$ of sampling sites possessed water unsuitable for drinking and other household works. The dominant sources of water pollution in this region are industrial effluents and domestic sewage. Both non-carcinogenic and carcinogenic health risks are invoked mostly from ingestion of $\mathrm{Co}$ and $\mathrm{Pb}$. Regular consumption of this tap water without further pretreatment may result in detrimental health consequences to both children and adults due to the physiological accumulation of toxic elements over time. This study highlighted a comprehensive scenario of the potentially toxic elements in the tap water of Dhaka city, which will allow policymakers to take adequate measures for sustainable water quality management.

Keywords: Tap-water; Dhaka city, Bangladesh; Dissolved potentially toxic elements; Water quality appraisement; Health risks estimation.

\section{Introduction}

Dhaka is ranked as the $19^{\text {th }}$ megacity $\left(300 \mathrm{~km}^{2}\right.$ area) around the world with more than 18 million people and a high population density ( 23,234 people $\left./ \mathrm{km}^{2}\right)$ (United Nations, 2016). Ensuring a safe water supply to this vast population is a real challenge. Dhaka Water Supply and Sewerage Authority (DWASA) is currently running with a daily production capacity of $\sim 2,550$ million-liter water per day using 887 deep wells and three water treatment plants (Haq, 2006; DWASA, 2019). In addition, more than 2000 private water pumps are abstracting water from different depths (DWASA, 2013; 2019). Those waters are distributed to city dwellers through the pipelines called tap-water.

Tap water (commonly known as faucet water, running water, or municipal water) is substantially distributed to the stakeholders of Dhaka City through the extraction of groundwater $(78 \%)$ or the treatment of the surface water (22\%). Almost $95 \%$ of Dhaka City dwellers depend upon this tap water for their daily household and other seminal purposes, including drinking, bathing, cooking, washing, toilet flushing, construction, and gardening (DWASA, 2019). Also, the supplied tap water is being consumed by lower and lower-middle-income families without any purification (Sharmin et al., 2020). Rising water demand by increasing population causes the 
annual incremental rate of groundwater extraction (Rahman et al., 2013), which leads to the depletion of groundwater table at least 2-3m per year (Haq, 2006; Hoque et al., 2007; Hossain et al., 2018; Bodrud-Doza et al., 2019a, b). Heavy industrialization, rapid urbanization, transportation, uncontrolled sewage discharge, and intensive agricultural activities adversely influenced the water supply, aquifer recharge, and peripheral rivers around Dhaka City (Rahman et al., 2013; Islam and Azam, 2015; Islam et al., 2016; Hossain et al., 2018; Bodrud-Doza et al., 2019b; Fakhri et al., 2017, 2018a, b; Ghasemidehkordi et al., 2018).

Sustainable Development Goal-6 (SDG-6), aims to ensure availability and sustainable management of fresh water and sanitation for all by 2030 (UN Water, 2018). Still, more than 80\% of people in Bangladesh lack clean and safe water (Yeazdani, 2016), and the uncontrolled existence of metal(oid)s like $\mathrm{Cr}, \mathrm{Cd}, \mathrm{Pb}, \mathrm{As}$, etc., are making the SDS-6 goal harder to achieve (UNICEF, 2009). Some metal(oid)s such as iron, zinc, and copper are necessary for physiological activities, but their bioaccumulation in excess is not desirable. On the contrary, some metal(oid)s such as arsenic, lead, cadmium, chromium, and mercury have no valuable functions in the body, and their increased concentration can cause toxic effects on the body tissues (Armitage et al., 2007; Yuan et al., 2011; Singh, et al., 2011; Gbadamosi, et al., 2018). Exposure to toxic metals may trigger numerous health risks including neurotoxicity, cardiovascular disease, renal problem, and reproductive failure (Fakhri et al., 2018a, b). Lead and Cd are well known for their long residence time in the human body and causing gastrointestinal inflammation, blood cerebral diseases, and pain in the bone (Itai-Itai disease) (Flora et al., 2012; Fagerberg et al., 2017). Therefore, continuous monitoring of these toxic elements in water and other environmental matrices is a prerequisite to safeguard human health. However, the types and severity of toxic effects are not proportional to the concentrations of toxic elements. Some toxic elements with low concentration exhibit much more significant health effect than others with high concentration (Adel et al., 2016; Çelebi et al., 2014; Saha and Zaman, 2013; Atapour 2012; Malakootian et al., 2014). The adverse effects of toxic elements may also vary depending on the physiological aspects of human health.

Few studies attempted to assess the groundwater quality of Dhaka and the probable health risks of Dhaka city dwellers (Sharmin et al., 2020; Bodrud-Doza et al., 2020; Sabrina et al., 2013). Bodrud-Doza et al. (2020) demonstrated that the children of the western part of the city were more prone to Fe and Mn exposure. According to Sharmin et al. (2020), the sublime concentration of 
$\mathrm{Pb}$ and $\mathrm{As}$ made $6.4 \%$ of groundwater unsuitable for drinking, and the residents who reside in the central-western portion of the city were more vulnerable to carcinogenic risks.

Although the recent studies focused on the groundwater quality and associated health risks in Dhaka city (Sharmin et al., 2020; Bodrud-Doza et al., 2020), a detailed investigation of supplied tap water quality in relation to dissolved metal(oid)s composition, and evaluation of associated health risks are yet to be done. The consumers of tap water in Dhaka city ( 95\% of total population) are often unsatisfied with the quality of supplied water due to its color and smell, and the levels of the toxic element are poorly known. It should be mentioned that the concentrations of metal(oid)s in the water in the water plants could be different than that of tap water due to corrosion-induced alteration of chemical composition during transportation through supply system (Faier et al., 2009; Kavcar et al., 2009; Khan et al., 2015; Shanbehzadeh et al., 2014). Considering the importance of this issue, the present study was aimed to (1) quantify the concentration of eleven metal(oid)s (Cr, Mn, Fe, $\mathrm{Co}, \mathrm{Ni}, \mathrm{Cu}, \mathrm{Zn}, \mathrm{As}, \mathrm{Cd}, \mathrm{Hg}$, and $\mathrm{Pb}$ ) in tap water, (2) utilize the entropybased water quality index for differentiating the tap water quality, (3) evaluate the potential sources and distributions of analyzed metal(oid)s using statistical and spatial mapping approaches, and (4) appraise probable cancer and non-cancer health risks for the city dwellers. To the best of our knowledge, this is the first study of its kind in the present study area. The outcomes of this study will help the government, responsible authorities, and policymakers undertake better management strategies and achieve the goal of SDG-6.

\section{Experimental and Methodologies}

\subsection{Study area}

Dhaka City stands in between $23.8103^{\circ} \mathrm{N}, 90.4125^{\circ} \mathrm{E}$ which is located almost in the middle of Bangladesh. According to DCC (Dhaka City Corporation), the city is covering an area of total $306.4 \mathrm{~km}^{2}$ and is bounded by a number of rivers, lakes, and differential water reservoirs. Major rivers in and around this city are Buriganga (south and west), Turag (northwest), Shitalakhya (northwest), Dhaleshwari (south) and Balu (east) (Islam et al., 2015). Among other water bodies Gulshan Lake, Dhanmondi Lake, Hatirjheel, Tongi-khal have a substantial impact on the hydrological cycle. A relatively flat topographic setting has the most advantageous outcome and its elevation varies from $0.5-12 \mathrm{~m}$ to the mean sea level (Hoque et al., 2007). Total four seasons circulate throughout the year like other parts of the country; around March to May is pre-monsoon, 
June to September is monsoon, October to November is post-monsoon and December to February is the dry season. The estimated average annual rainfall is over $2000 \mathrm{~mm}$ from which nearly 8090\% occurs during the monsoon period (Banglapedia, 2018). Monthly average temperatures range between $25-31{ }^{\circ} \mathrm{C}$ and average humidity and evaporation range between $80-90 \%$, and $80-130 \mathrm{~mm}$ respectively (BMD, 2016). Water-logging, unplanned sewage system, untreated industrial waste disposal, drainage congestion, lack of management of domestic waste, etc. are a quite familiar scenario of the city for a long time (Rahman et al., 2012; Islam and Azam, 2015; Islam et al., 2016; Bodrud-Doza et al., 2020). Fig. 1 shows the exact location by coordinates of the sampling sites from Dhaka City where purple circles indicate the sampling points.

\subsection{Sample collection, processing, and analysis}

A total of 34 household tap-water samples were collected from thirty-four different locations (Fig. 1) of Dhaka metropolitan city. However, required sample information and ancillary data for the analyzed tap water samples are tabulated in Table 1. All samples were collected during September 2020 (monsoon). Water samples were collected in thoroughly prewashed 1L capacity high-quality polyethylene water bottles. At the time of sampling, faucets were opened for $\sim 5$ minutes; hereafter, water bottles were rinsed several times with sample water of a particular location. Sampling bottles were then completely filled with the tap-water sample and closed the cap tightly. Probable all types of precautions were taken to omit the unenvied contamination during sampling and rinsing. However, the overall course of sampling was simple random sampling where all the locations were selected randomly; thus, the process of sampling can also be deliberated as cluster area sampling. In the analytical laboratory, Flame Atomic Absorption Spectrophotometer (AAS-6800, Shimaddzu Corporation, Japan) was used to analyze the elemental concentrations of $\mathrm{Cr}, \mathrm{Mn}, \mathrm{Fe}, \mathrm{Co}, \mathrm{Cu}, \mathrm{Zn}$, and $\mathrm{Pb}$ in the sample water after consecutive acid digestion with concentrated $\mathrm{HNO}_{3}$ acid followed by required dilutions (Ahmed et al., 2021; Rahman et al., 2020). Besides, concentrations of $\mathrm{Ni}$ and $\mathrm{Cd}$ were determined by Zeeman-AAS (Model-GTA 120AA240Z, Varian, Australia) whereas elemental abundances of As and $\mathrm{Hg}$ in tap-water samples were measured by Hydride vapor generation technique of AAS (Model-Spectra AA 220 equipped with ETC-60 \& VGA-77, Varian, Australia). The quality control schemes applied in this research were, however, exactly the same as in previous studies (Ahmed et al., 2021; Habib et al., 2020; Islam et al., 2020; Ahsan et al., 2019). 


\subsection{Water quality index}

Shannon (1948) expressed the concept of entropy as a criterion of measuring the information or uncertainty that can predict the outcome of a probabilistic occurrence (Guey-Shin

157 et al., 2011). Herein, the following steps are involved to appraise the water quality by using the 158 entropy principle (Islam et al., 2020). For estimating the entropy weight for $\mathrm{m}(\mathrm{i}=1,2, \ldots, \mathrm{m})$ 159 number of water samples with $\mathrm{n}(\mathrm{j}=1,2, \ldots, \mathrm{n})$ number of analyzed parameter, Eigen-value matrix $160 \mathrm{X}$ can be computed by eq. (1).

$X=\left[\begin{array}{ccc}\mathrm{x}_{11} & \mathrm{x}_{12} \cdots & \mathrm{x}_{1 \mathrm{n}} \\ \mathrm{x}_{21} & \mathrm{x}_{22} \cdots & \mathrm{x}_{2 \mathrm{n}} \\ \vdots & \vdots & \vdots \\ \mathrm{x}_{\mathrm{m} 1} & \mathrm{x}_{\mathrm{m} 2} \cdots & \mathrm{x}_{\mathrm{mn}}\end{array}\right]$

162 To diverge the influences of various units and contents of analyzed parameters, efficiency type 163 (eq. 2) normalization approach (Pei-Yue et al., 2010) was obtained to convert the eigen value 164 matrix (X) into a standard grade matrix (Y) (eq. 3).

$165 \quad Y_{i j}=\frac{X_{i j}-\left(X_{i j}\right)_{\min }}{\left(X_{i j}\right)_{\max }-\left(X_{i j}\right)_{\min }}$

$166 \quad Y=\left[\begin{array}{ccc}\mathrm{y}_{11} & \mathrm{y}_{12} \cdots & \mathrm{y}_{1 \mathrm{n}} \\ \mathrm{y}_{21} & \mathrm{xy}_{22} \cdots & \mathrm{y}_{2 \mathrm{n}} \\ \vdots & \vdots & \vdots \\ \mathrm{y}_{\mathrm{m} 1} & \mathrm{y}_{\mathrm{m} 2} \cdots & \mathrm{y}_{\mathrm{mn}}\end{array}\right]$.

167 Then the ratio of the analyzed parameter index $\left(\mathrm{P}_{\mathrm{ij}}\right)$, information entropy $\left(\mathrm{e}_{\mathrm{j}}\right)$, and entropy weight $168\left(\omega_{\mathrm{j}}\right)$ can be calculated by eqs. (4-6).

$169 \quad P_{i j}=\frac{Y_{i j}}{\sum_{i=1}^{m} Y_{i j}} \ldots \ldots \ldots . . . .(4)$

$170 \quad e_{j}=-\frac{1}{\ln (m)} \sum_{i=1}^{m}\left(P_{i j} \times \ln P_{i j}\right)$

$171 \omega_{\mathrm{j}}=\frac{1-\mathrm{e}_{\mathrm{j}}}{\sum_{\mathrm{j}=1}^{\mathrm{m}}\left(1-\mathrm{e}_{\mathrm{j}}\right)} \ldots \ldots \ldots \ldots$

172 Quality rating scale for the analyzed parameter $(\mathrm{j})$ can be calculated from the obtained data $\left(\mathrm{C}_{\mathrm{j}}\right)$ 173 and the standard data $\left(S_{j}\right)$ by eq. (7).

$174 \quad q_{j}=\frac{C_{j}}{s_{j}} \times 100$

175 From eqs. (6) and (7), EWQI can be determined by eq. (8).

$176 \quad E W Q I=\sum_{j=1}^{n} \omega_{j} q_{j}$ 
Here, the estimation of two significant parameters including information entropy $\left(\mathrm{e}_{\mathrm{j}}\right)$ and entropy weight $\left(\omega_{\mathrm{j}}\right)$ are tabulated in Table 2 those are required to elucidate the water quality in terms of EWQI. According to the EWQI value, water samples can be classified into five grades based on the suitability of human consumption. Herein, grade one $(\mathrm{EWQI}<50)$ is excellent to use for drinking purpose; followed by grade two $(50 \leq \mathrm{EWQI}<100)$ which is good and suitable for drinking; grade three $(100 \leq \mathrm{EWQI}<150)$ is moderate and suitable for domestic, irrigation, and industrial uses, albeit require further treatment for using in drinking purpose, grade four $(150 \leq \mathrm{EWQI}<200)$ is earmarked as poor and not suitable for drinking; and lastly, grade five (EWQI $\geq 200)$ which is considered as extremely poor quality water and thoroughly inadmissible for human consumption (Islam et al., 2020; Siddique et al., 2021; Ahmed et al., 2021).

\subsection{Statistical approaches}

The measured analytical parameters were evaluated statistically by SPSS-software (Version-20, IBM-Corporation, Armonk, NY, USA). To determine the important factor, interrelationship, specific pollution source of the tap-water, multivariate statistical methods (Pearson correlation analysis, cluster analysis, and principal component analysis) were applied in the present study (Khan et al., 2019; Ahsan et al., 2019; Islam et al., 2018). Principal component analysis (PCA) with a Varimax rotation method was utilized to extract principal components (PCs) from the sampling points, to evaluate spatial variations and possible source of pollution in groundwater, and to determine the degree of pollution (Bodrud-Doza et al., 2016; Islam et al., 2018). On the other hand, cluster analysis was performed with Ward algorithmic method and rescaled linkage distance of similarity calculates the similarity among elemental components from different sources with the help of various sample groups (Lattin et al., 2003; Bhuiyan et al., 2016). Moreover, the dendrogram contributed by giving a visual summary of a different cluster as well as their proximity (Bodrud-Doza et al., 2016). Pearson correlation analysis was executed to show the relevant associations among the analyzed parameters in a certain cluster (Islam et al., 2019).

\subsection{Health risk estimation}

Health risk estimation is the likelihood of any given enormity of adverse health effects amid a specific time (Bortey-Sam et al., 2015; Bodrud-Doza et al., 2020). This estimation is usually based on the risk level ascertainment and disclosed by carcinogenic and non-carcinogenic health 
risks (USEPA, 2009). Direct oral ingestion and dermal absorption by the skin are generally considered for the evaluation of health risks induced by trace elements in water (Zeng et al., 2015). According to USEPA (2004), the exposure doses for direct ingestion ( $\left.\mathrm{ADD}_{\text {ingestion}}\right)$ and dermal absorption $\left(\mathrm{ADD}_{\text {dermal }}\right)$ are expressed as bellow:

$A D D_{\text {ingestion }}=\frac{\mathrm{C}_{\mathrm{W}} \times \mathrm{IR} \times \mathrm{Abs}_{\mathrm{g}} \times \mathrm{EF} \times \mathrm{ED}}{\mathrm{BW} \times \mathrm{AT}}$

$A D D_{\text {dermal }}=\frac{\mathrm{C}_{\mathrm{W}} \times \mathrm{SA} \times \mathrm{K}_{\mathrm{p}} \times \mathrm{EF} \times \mathrm{ET} \times \mathrm{ED} \times 10^{-3}}{\mathrm{BW} \times \mathrm{AT}}$.

Where, $\mathrm{C}_{\mathrm{w}}, \mathrm{IR}, \mathrm{EF}, \mathrm{SA}, \mathrm{ET}, \mathrm{ED}, \mathrm{BW}, \mathrm{AT}, \mathrm{Abs}_{\mathrm{g}}$, and $\mathrm{K}_{\mathrm{p}}$ represent the concentrations of trace elements $\left(\mu \mathrm{gL}^{-1}\right)$, ingestion rate $\left(\mathrm{L} \cdot \mathrm{day}^{-1}\right)$, exposure frequency (days.year $\left.{ }^{-1}\right)$, exposed skin area $\left(\mathrm{cm}^{2}\right)$, exposure time (h.day ${ }^{-1}$ ), exposure duration (in years), body weight (in $\mathrm{kg}$ ), average time for non-carcinogens (days), gastrointestinal absorption factor, and dermal permeability coefficient $\left(\mathrm{cm} \cdot \mathrm{h}^{-1}\right)$, respectively. The values of each parameter are tabulated in Table S1. Besides, noncarcinogenic health hazard can be calculated from the estimation of Hazard Quotient for both oral ingestion and dermal exposure from the following eqs. (11-13).

$\mathrm{HQ}$ ingestion $=\frac{\mathrm{ADD}_{\text {ingestion }}}{\mathrm{R}_{\mathrm{f}} \mathrm{D}_{\text {ingestion }}}$

$H Q_{\text {dermal }}=\frac{A D D_{\text {dermal }}}{R_{\mathrm{f}} D_{\text {dermal }}}$

$\mathrm{R}_{\mathrm{f}} \mathrm{D}_{\text {dermal }}=\mathrm{R}_{\mathrm{f}} \mathrm{D}_{\text {ingestion }} \times \mathrm{Abs}_{\mathrm{g}}$

Here, $R_{f} D_{\text {ingestion }}$ and $\mathrm{R}_{\mathrm{f}} \mathrm{D}_{\text {dermal }}$ are the reference doses for individual elements $\left(\mu \mathrm{g} \cdot \mathrm{kg}^{-1}\right.$.day $\left.{ }^{-1}\right)$ which are also presented in Table S1 (USEPA, 2011, 2004). However, the Hazard Quotient (HQ) evaluation considers the possible degree of harmfulness for each type of hazard whereas the total potential non-carcinogenic health hazard can be calculated by Hazard Index (HI) from the following eq. (14).

$\mathrm{HI}=\sum_{\mathrm{i}=1}^{\mathrm{n}}\left(\mathrm{HQ}_{\text {ingestion }}+\mathrm{HQ}_{\text {dermal }}\right)$

When the HI value is less than 1, no potential hazard for water pollution, contrariwise, when the value is more than 1, there is a probable risk of hazardous impact to the water. Consequently, noncarcinogenic health hazards can be considered, only when the values of HQ and HI are >1. Moreover, exposure to more than one metal contaminant may cause additive and/or interactive effects, and hence, accretive health effect from multiple metals' exposure can be calculated by summing Total Hazard Quotient (THQ) value of the individual metal that expressed as Total Target Hazard Quotient (TTHQ) from the following eq. (15) (Fakhri et al., 18a): 
$T T H Q=T T H Q_{C r}+T T H Q_{M n}+T T H Q_{F e}+T T H Q_{C o}+T T H Q_{N i}+T T H Q_{C u}+T T H Q_{Z n}+T T H Q_{A s}+$

$238 T H Q_{C d}+T H Q_{H g}+T T H Q_{P b}$

239 TTHQ value $>1$ introduces the likelihood of untoward health consequences and indicates the 240 concernment of further investigation approaches and probable preclusive measures whereas TTHQ $241<1$ represents no possible risk of health hazard from the exposure of analyzed metals at present 242 consumption rates (Fakhri et al., 2018a, b).

243 On the other hand, Carcinogenic Risk (CR) for both oral ingestion and dermal exposure can be 244 estimated from the eq. (16) and (17) whereas total carcinogenic risk can be calculated from the eq 245 (18). Hence, the equations are as follows:

$246 \quad \mathrm{CR}_{\text {ingestion }}=\mathrm{ADD}_{\text {ingestion }} \times \mathrm{CSF}_{\text {in }}$

$247 \quad \mathrm{CR}_{\text {dermal }}=\mathrm{ADD}_{\text {dermal }} \times \mathrm{CSF}_{\text {dermal }}$

248

$\mathrm{CR}_{\text {total }}=\mathrm{CR}_{\text {ingestion }}+\mathrm{CR}_{\text {dermal }}$

249 Here, CSF is the Cancer Slope Factor $(\mathrm{mg} / \mathrm{kg} / \text { day })^{-1}$. In this work, the CR ingestion was estimated for

$250 \mathrm{Cr}, \mathrm{Ni}, \mathrm{As}, \mathrm{Cd}$, and $\mathrm{Pb}$; and $\mathrm{CR}$ dermal was estimated for only As (as standard dermal CSF for other 251 metals were not available). However, the CSFs are 0.00038, 0.00091, 0.0015, 0.041, and 0.0085

$252(\mathrm{mg} / \mathrm{kg} / \text { day })^{-1}$ for ingestion intake respectively, whereas, dermal CSF for As is 0.00366

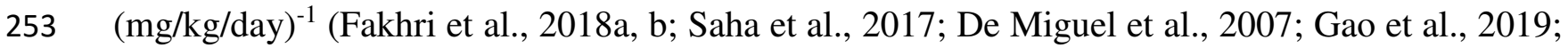
254 Siddique et al., 2021; Ahmed et al., 2021). The acceptable or tolerable range of carcinogenic risks 255 is $1.0 \times 10^{-6}$ to $1.0 \times 10^{-4}$ (USEPA, 2004, 2011).

256

257 3. Results and Discussion

2583.1 Metal(oid)s in tap water and their distributions

259 Concentrations of metal(oid)s (Cr, Mn, Fe, Co, Ni, Cu, Zn, As, Cd, Hg, and Pb) in the 260 analyzed tap water samples are tabulated in Table 2. The concentration of $\mathrm{Cr}$ was found with an 261 average of $43.1 \pm 44.5 \mu \mathrm{g} / \mathrm{L}$, which is slightly lower than the national and international 262 recommended limits (Table 2, Fig. 2). However, Cr concentration in some earmarked samples, 263 including W-12 (Bosila), W-20 (Demra), W-1 (Abdullahpur), W-8 (ECB), W-33 (Goran), and W2649 (Monipur school), W-22 (Matuail), W-27 (Badda), W-34 (Mohammadpur) were >2 times higher 265 than the prescribed limits (WHO 2004, 2011; ECR, 1997; EPA 2001; EU 1998; BIS 1991) (Table $2662)$. 
However, $\mathrm{Fe}$ in all the analyzed tap water samples was found to be significantly higher than the international permissible limits and $\sim 75 \%$ of the samples possess much higher Fe than the national recommended value for drinking water (WHO 2004, 2011; ECR, 1997; EPA 2001; BIS 1991) (Table 2, Fig. 2). Cobalt concentrations in several samples including W-7, W-8, W-17, W26, W-32, W-33, and W-34 were found slightly higher than the permissible limit of WHO, (2011) and USEPA (2004) (Table 2). The concentration of Ni was found within the range of 7-101 $\mu \mathrm{g} / \mathrm{L}$ with an average of $30 \pm 24 \mu \mathrm{g} / \mathrm{L}$. Here, only a single sample W-12 (Bosila) was ascertained slightly upper than the national water quality guideline (ECR, 1997) whereas W-22, W-33, and W-34 possess higher Ni-content than the recommended value of WHO (2011) (Table 2). Concomitantly, $\mathrm{Cu}, \mathrm{Zn}, \mathrm{As}$, and $\mathrm{Hg}$ concentrations were determined much lower than the national and international permissible limits (Table 2, Fig. 2). Cd concentrations for all the samples were lower than the national recommended value (ECR, 1997), albeit $~ 33 \%$ of the analyzed samples possess slightly higher Cd-content compared to the permissible limit of WHO $(2004,2011)$ (Table 2, Fig 2). The average $\mathrm{Pb}$ concentration was found $32.9 \pm 28.4 \mu \mathrm{g} / \mathrm{L}$ which was upper than the guideline value of WHO (2011), EPA (2001), and EU (1998) (Fig. 2). Besides, six samples ( 18\%) including W-3 (Ashkona), W-4 (Dakkhinkhan), W-9 (Monipur School), W-14 (Khilgoan), W-26 (Notunbazar), and W-32 (Shankar) were obtained significantly higher than the accepted limit proposed by the ECR (1997) (Table 2).

Moreover, Table 2 also represents the comparison between some existing literature data (Zakir et al., 2020; Saha et al., 2019; Rahman et al., 2013; Bodrud-doza et al., 2020; Kumar et al., 2019; Maw et al., 2020; Abeer et al., 2020; Muhammad et al., 2011; Mohammadi et al., 2019; Qiao et al., 2020; Dong et al., 2020; Nguyen et al., 2020; Le bot et al., 2016; Momot et al., 2005; Szuster-Janiaczyk et al., 2018; Abdeldayem, 2019; Opoku et al., 2020; Egbueri et al., 2020) and the determined heavy metal(oid)s concentrations in the tap water samples of the present study. In comparison to literature data, the mean concentration of $\mathrm{Fe}, \mathrm{Cr}, \mathrm{Pb}, \mathrm{Co}, \mathrm{Ni}, \mathrm{Cd}$ were obtained significantly higher than the tabulated literature data, contrariwise, As concentration in the present study were much lower than the literature data. Hence, the above discussions unravel that in the present study the sublime concentrations of $\mathrm{Fe}, \mathrm{Cr}$, and $\mathrm{Pb}$ in the analyzed tap-water samples are indicating a pernicious threat to the consumers whereas the concentrations of $\mathrm{Co}, \mathrm{Ni}$, and $\mathrm{Cd}$ were significantly higher than the listed previous studies (Table 2). 
Consequently, distributions of both analyzed metal(oid)s and the total population number of the specific sampling area are represented by spatial distribution maps in Fig. 3. The population distribution map shows that the Central-Northern portion of Dhaka city is a significantly most populated area and thus if a particular carcinogenic or non-carcinogenic heavy metal is counted as predominant there, it will affect a huge population.

However, the sublime concentration of $\mathrm{Cr}, \mathrm{Fe}, \mathrm{Ni}, \mathrm{Cu}$, and $\mathrm{Cd}$ were found in the Southern part of the city. Principally, several industrial effluent disposals in the surface water including chemical industry, textile industry, production of dyes, wood preservation, leather tanning, chrome plating, manufacturing of various alloys might be liable for the intemperance concentration of $\mathrm{Cr}$, $\mathrm{Ni}, \mathrm{Cu}$, and $\mathrm{Cd}$ in the tap water where the concentration of $\mathrm{Fe}$ naturally depends on the groundwater aquifer (Tumolo et al., 2020; Hossain et al., 2015; Zhitkovich, 2011). Moreover, South-Eastern areas are predominant with several export-oriented industries including textiles, apparel, leather, jute, cement, ceramics, steel mills, etc. (Britannica, 2019). A high concentration of Mn was determined in the three different portions of Dhaka city such as W-3 (Eastern), W-7 (Central), and W-18 (Western). Albeit, naturally occurring Mn in the groundwater is considered as the principal source of $\mathrm{Mn}$ in the tap-water (Frisbie et al., 2012). The maximum affluence of $\mathrm{Co}, \mathrm{Cu}$, and $\mathrm{Pb}$ were found in the Western part of the city and thus, the populations of these areas are at the risk of excessive exposure to these elements. Industrial effluents, agricultural and urban run-off, and the geology and geochemistry of a particular area might be responsible for the surpassed concentration of these elements in the tap-water (Atashi et al., 2009). Furthermore, $\mathrm{Ni}$ and $\mathrm{Pb}$ concentrations were also determined significantly orient in the Northern part whereas the ascendant concentration of $\mathrm{Zn}$ was determined in the Eastern part of Dhaka city. Several sampling points from different parts of the city including W-14 (Khilgaon), W-15 (Maradia), W-21 (Jatrabari), and W-23 (Kalshi) were obtained high concentration of $\mathrm{Hg}$ which indicating the sources of tap-water of these locations probably contaminated with hazardous waste (Verma et al., 2018). Albeit, in some cases, pipeline complications may be induced due to the contact of soft acidic water with the household plumbing, faucets, and water fixtures that results in corrosion and might be incrementing the concentration of several elements including $\mathrm{Fe}, \mathrm{Ni}, \mathrm{Cu}$, and $\mathrm{Pb}$ in the tap-water (McNeill and Edwards, 2001; WHO, 2005; Björn et al., 2003; USEPA, 2011).

Hence, the spatial distribution of the trace elements revealed that sampling point W-7 (Kafrul), W-21 (Jatrabari), and W-33 (Goran) are immensely loaded with four different types of 
trace metal(oid)s and followed by sampling point W-14 (Khilgaon); W-27 (Badda), and W-32 (Shankar) are also stately loaded with three diverse types of trace elements, respectively. As a result, the populations of the above-mentioned areas are at the highest possible risks of metalinducing hazards.

\subsection{Water quality assessment}

Tap-water quality has been assessed based on two criteria: (1) Comparing the concentration of the analyzed dissolved metal(oid)s with the national and international recommended guideline values for water; and (2) Quantifying the suitability of tap water for the human consumption using entropy water quality index (EWQI). This study found that the average Fe concentration in the analyzed water samples was obtained more than 3 times higher than the national permissible limit of ECR (1997) and approximately more than 10 times higher than the international standard guideline values proposed by WHO (2011), EPA (2001) and BIS (1991) (Table 2, Fig. 2). Besides, the obtained mean concentration of Ni was found higher than the admissible limit of EPA (2001) and EU (1998) while the average abundances of $\mathrm{Pb}$ were determined 3 times higher than the acceptable limit of WHO (2011), EPA (2001) and EU (1998) (Table 2, Fig 2). Hence, only the mean concentration of $\mathrm{Fe}$ was found to transgress both the national and international permissible limit and the rest of the metal's average abundances were determined lower than the national admissible standard. However, as per the Environmental Conservation Rule (ECR, 1997), all of the analyzed tap-water samples were contaminated with the presence of excess Fe concentration whereas some specific samples are also contaminated with several trace elements $(\mathrm{Cr}, \mathrm{Pb}$, and $\mathrm{Ni})$ (Table 2) in the perspective of Bangladesh.

In addition, to evaluate the pertinence of the collected tap-water samples, the entropy water quality index (EWQI) has been used as it is a more reliable and globally recognized approach compare to the assumption-based weighing method. More importantly, EWQI is the more justified and acceptable technique as it can minimize the relative error by logically identifying the weight of every analyzed parameter (Ahmed et al., 2021; Pei-Yue et al., 2010). Furthermore, the prime impactful analytical parameter can be determined by calculating these two entropy parameters $\left(\omega_{j}\right.$ and $\left.e_{j}\right)$, for instance, any parameter with higher entropy weight $\left(\omega_{j}\right)$ and lower information entropy

$\left(\mathrm{e}_{\mathrm{j}}\right)$ value indicating that the parameter has a heavier impact on the general water quality (Siddique et al., 2021; Islam et al., 2020; Gorgij et al., 2017). The results of these two entropy parameters in 
Table 2 show that $\mathrm{Cr}, \mathrm{Fe}$, and $\mathrm{Pb}$ have the higher $\omega_{\mathrm{j}}$ value and lower $\mathrm{e}_{\mathrm{j}}$ value, implying that these elements have maximum impact on the water quality relative to the other analyzed metal(oid)s. Hence, based on the obtained values of entropy weight $\left(\omega_{\mathrm{j}}\right)$ and information entropy $\left(\mathrm{e}_{\mathrm{j}}\right)$ (Table 2$)$, the effects of variables on overall water quality are followed in the decreasing order: $\mathrm{Cr}>\mathrm{Fe}>\mathrm{Pb}>\mathrm{Zn}>\mathrm{Ni}>\mathrm{As}>\mathrm{Mn}>\mathrm{Hg}>\mathrm{Cu}>\mathrm{Cd}>\mathrm{Co}$.

The value of EQWIs for every tap water sample has been calculated by using eqs. (1-8) and later, ranked these samples based on obtained EWQI values. And however, this index classification provides a firm stance of water decency by ascertaining only a single number in a relatively simple way. Here, Fig. 4a depicts the status of all the tap-water samples whereas Fig. 4b represents the distribution of EWQI-values over the different sampling points. According to the rank of EWQI standard value, sampling point W-32 (Shankar) and W-24 (Kotwali) are categorized as 'extremely poor' while W-18 (Lalbagh) and W-33 (Goran) are earmarked as 'poor' quality water and totally unsafe for human consumption without any treatment (Fig. 4a). Besides, EWQI values of sampling point W-13 (Tejgaon), W-9 (Monipur School), W-1 (Abdullahpur), W-14 (Khilgaon), and W-7 (Kafrul) are found within 100-150, thus, they are classified as 'moderate' quality water that can be used for domestic, irrigation, and industrial purposes but require further treatment for drinking; subsequently, rest of the samples are categorized as 'good' and 'excellent' quality of water which are completely suitable for drinking (Fig. 4a). Thus, $73.6 \%$ (W: 2-6, 8, $10-12,15-17,19-23,25-31$, and 34) of tap-water samples are safe and suitable for direct human consumption (marked as 'excellent and good') whereas $\sim 14.7 \%$ (W: 1, 7, 9, 13, and 14) of samples are suitable for usage in household and other purposes (marked as 'moderate'), and 11.8\% (W: $18,24,32$, and 33) of samples are thoroughly impermissible for drinking (marked as 'poor and extremely poor') based on the EWQI rankings (Table 2 and Fig. 4). In addition, the distribution map (Fig. 4b) represents that extremely poor, poor, and moderate-quality tap water are predominant in the South-Western and Southern parts. Contrariwise, good and excellent quality tap water are flourishing in the Eastern and Northern part of the city.

\subsection{Source apportionment}

Principal component analysis (PCA) works as a substantial tool in finding the pattern of resemblance among a set of observations (Abdi \& Williams, 2010). PCA was used to identify the possible source and groupings of the analyzed heavy metals in thee collected tap water samples. 
PCA extracted five factors from the measured metal(oid)s in water with Eigenvalues $>1$ which is shown in the scree plot (Fig. S1) (Liu et al., 2013). The initial data dimensions of the analyzed elements are reduced into five loading factors without considerable loss of data and about $69.15 \%$ of the total variance is explained by those factors (Table S2). PC1 which is accounted for $15.76 \%$ of the total variance, showed strong positive loadings for As and $\mathrm{Hg}$. Arsenic and mercury contamination in the studied area might have come from paint, pharmaceutical, paper, and pulp preservatives, chlorine, and caustic soda production industries, fertilizer and pesticide industries (Aradhi et al., 2009; Krishna and Mohan, 2014; Morais et al., 2012). Pollutant disposal from this kind of pollutants may be possible in the surface water bodies of Dhaka city from where water is supplied to the households after treatment. Hence, probable inefficient removal of pollutants in the treatment plants may be another issue. PC2 explained $14.96 \%$ of the total variance showing strong positive loadings for $\mathrm{Cr}$ and $\mathrm{Ni}$. Metal industries, leather and tanneries, painting, and cement industries are the primary sources of $\mathrm{Cr}$ in the water (Martin and Griswold, 2009). Ni could be present due to both anthropogenic and natural sources like vehicle exhaust, domestic effluents, or from weathering process due to disintegration of parent mineral (Tatsi et al., 2015). Both Ni and $\mathrm{Cr}$ can be released in the tap water system from corrosion of galvanized metallic pipes (Peng et al., 2012). The positioning of these two elements in the same PC may have been resulted from the dominance of corrosion from distribution system. On the contrary, PC3 accounted for $13.35 \%$ of total variance with the moderate loadings for $\mathrm{Mn}, \mathrm{Fe}$, and $\mathrm{Pb}$. Generally, Fe and $\mathrm{Mn}$ occur naturally in groundwater because of dissolution from minerals (Wendland et al., 2005). They can also be generated from mining and industrial wastes. $\mathrm{Fe}$ and $\mathrm{Pb}$ might be present in water due to contamination from metal and alloy industries or these may come from poor plumbing works while transporting (Bhuiyan et al., 2011, 2016). PC4, explaining 13.28\% of the total variance showed a strong positive loading for $\mathrm{Cu}$ and $\mathrm{Zn}$. The simultaneous high loadings of these two elements may occur from galvanic corrosion (Cartier et al., 2012). Presence of $\mathrm{Zn}$ and $\mathrm{Cu}$ also suggest the influence from domestic sewage (Wang et al., 2017) or other forms of organic materials (Gonzalez et al., 2013). PC5 explained $11.79 \%$ of the total variance and showed strong negative loading for Co while strong positive loading for $\mathrm{Cd}$. Presence of cadmium might be attributed to various industrial effluent of chemical, electrical, steel industries, and agricultural runoff (Wu et al., 2009; Huang et al., 2014; Wagh et al., 2018). Cobalt can be present in the aquatic system from both geogenic and anthropogenic causes. The anthropogenic causes for $\mathrm{Co}$ in water includes the 
421 production of alloys and chemicals, contamination from sewage, agricultural pollution etc (Kim et

422 al., 2006). However, the opposite loadings between Co and Cd probably reflects the alternative dissolution source or characteristics of these two metals. Similar loadings of element in a component indictaes their common source of origin in the water. Depending on the level of analyzed elements, the PCA for 34 sampling sites extracted two components explaining 99.60\% of the total variance (Table S3) in which most of the sampling sites loaded strongly and positively.

Based on the information derived from PCA, hierarchical cluster analysis (CA) was also employed to detect spatial similarities of the anlyzed elements in the water samples (Ahsan et al., 2019) from the measured parameters (R-mode) and sampling sites (Q-mode) with Ward's method and the Euclidean distance as a measure of similarity (Fig. S2). The elements grouped in CA in each cluster mostly supports the result of PCA which gives validation of the determination.

Pearson's correlation matrices were utilized to identify the associations among the analyzed elements (Tamim et al., 2016; Hasan et al., 2020), and the results are tabulated in Table S4. The strong and significant correlations among the parameters indicate their common sources of origin(s). Most of the correlations show poor and insignificant values indicating less probability of coherence of their source of origin. However, the positioning of the elements in PCA is strongly supported by the correlation analysis since significant correlation has been observed for the parameters from the same PC or cluster (R-type). For instance, $\mathrm{Cr}$ and $\mathrm{Ni}$ which were loaded positively on PC2 also showed a significant positive association (0.526) in the correlation analysis. The moderate and significant correlation between $\mathrm{Cr}$ and $\mathrm{Ni}$ indicates the leaching from stainless steel pipes (Schwenk, 1991) or the influence by the contamination from different industries in the source water (Dessie et al., 2021). $\mathrm{Cu}$ and $\mathrm{Zn}$ which are loaded positively on PC4, showed a significant positive correlation (0.390) among them. Hence, similar source(s) for these two metals can be anticipated. As and $\mathrm{Hg}$ showed significant and moderately positive correlation (0.474) between them, and they were positioned in PC1. The other correlations show weak values and insignificance suggesting the absence of coherent sources for different materials.

\subsection{Health risk assessment}

Possible non-carcinogenic and carcinogenic health risks through ingestion and dermal pathways were estimated for both adults and children. By using risk factors, hazard quotient (HQ) 
and hazard index $(\mathrm{HI})$ deduced the overall potential health risk exposure originated from elemental abundances of toxic metal(oid)s in the existing samples all over Dhaka City (Fig. 5).

Non-carcinogenic health appraisals for eleven trace metal(oid)s are depicted in the Fig. 5a, for $\mathrm{Cr}, \mathrm{Mn}, \mathrm{Fe}, \mathrm{Co}, \mathrm{Ni}, \mathrm{Cu}, \mathrm{Zn}, \mathrm{As}, \mathrm{Cd}, \mathrm{Hg}$, and $\mathrm{Pb}$. In the case of, $\mathrm{HQ}_{\text {ing }}$ and $\mathrm{HQ}_{\text {der }}$ the health risk for metals seemed benign $(\mathrm{HQ}<1)$ except for Co presence in children, which exceeded the threshold limit $(\mathrm{HQ}=1)$ for both ingestion and dermal ( $\left.\mathrm{HQ}_{\mathrm{ing}}=1.85, \mathrm{HQ}_{\mathrm{der}}=1.96\right)$. HQ for ingestion of Co through the intake of sample water also exceeded the safest limit for adults ( $\left.\mathrm{HQ}_{\mathrm{ing}}=1.28\right)$. Overall, calculated hazard index for non-carcinogenic risk followed a decreasing trend of $\mathrm{Co}>\mathrm{Cr}>\mathrm{As}>\mathrm{Ni}>\mathrm{Pb}>\mathrm{Cd}>\mathrm{Cu}>\mathrm{Fe}>\mathrm{Hg}>\mathrm{Mn}>\mathrm{Zn}$ (Fig 5a). This indicated that tap water from all the sampling sites could induce Co-related health risk as it surpassed the safe limit of hazard index ( $\mathrm{HI}_{\text {adult: }}$ 1.35, $\mathrm{HI}_{\text {children: }}$ 3.94). Even slightly higher concentration than the required level of Co for the human body can provoke potential non-carcinogenic risk, which might associate with rhinitis and dermatitis (Wang et al., 2017; Fang et al., 2014). Individually, the W-7(Kafrul) sample significantly contributed to the Co exposure (Adult: 3.06, Children: 6.09), much higher than the recommended value. For the values of $\mathrm{Cr}$ and $\mathrm{As}, \mathrm{HQ}_{\mathrm{ing}}, \mathrm{HQ}_{\mathrm{der}}$, and $\mathrm{HI}$ are highly close to the threshold limit, which might impose a health risk if not maintained carefully. In case of $\mathrm{Cr}$ and $\mathrm{As}$, $\mathrm{Cr}$ exhibited higher HI values which could possess greater risk for children ( $\mathrm{HI}_{\text {children: }}$ 0.75) compared to adults $\left(\mathrm{HI}_{\mathrm{adult}}\right.$ : 0.16). This may be related to various skin problems, allergic inflammation (SCHER, 2015), and chromosomal aberrations (O'Brien et al., 2001; Matsumoto et al., 2006). Furthermore, total target hazard quotient (TTHQ) values (Fig. 5b), calculated by combining the HQs from all the measured metal(oid)s of which greater than 1 indicates possible non-carcinogenic human health effects (Fakhri et al., 2018a, b). The TTHQ of children for both ingestion and dermal values is 2.2 and 2.87, respectively, indicating a potential health risk for that age group. On the other hand, TTHQ ${ }_{\text {ingestion }}$ and $\mathrm{TTHQ}_{\text {dermal }}$ values for adults are 1.51 and 0.97, respectively, indicating the risk is higher by ingestion route for adults rather than dermal contact.

Potential carcinogenic health hazards for $\mathrm{Cr}, \mathrm{Ni}, \mathrm{As}, \mathrm{Cd}$, and $\mathrm{Pb}$ are evaluated through average daily dose with cancer slope factor (Fig. 5c). The measured parameters for carcinogenic health risk followed a decreasing trend, i.e., $\mathrm{Pb}>\mathrm{As}>\mathrm{Ni}>\mathrm{Cd}>\mathrm{Cr}$. From Fig. $5 \mathrm{c}, \mathrm{Pb}$ delineated the highest value for both age groups (adults: $8.96 \times 10^{-4}$, children: $1.20 \times 10^{-3}$ ), which surpassed the safe limit of $1 \times 10^{-4}$, which might be accountable for arthritis, renal dysfunction, autism, dyslexia, and other birth defects (Martin \& Griswold, 2009). From Fig. 5d, calculated total cancer risk (TCR) 
is also higher for Arsenic (As) which is much closer to the threshold value for both adult (TCR: $4.71 \times 10^{-5}$ ) and children (TCR: $9.87 \times 10^{-5}$ ) age group indicated that regular use of the tap-water in Dhaka City over some time would increase the probability of cancer. Except for lung, skin, and bladder cancer, chronic arsenic toxicity might cause pigmentation and keratosis (Martin \& Griswold, 2009). Altogether, this study elucidates that Co can initiate potential non-carcinogenic health risks, while $\mathrm{Pb}$ may instigate potential carcinogenic health risks for both age groups as they exceeded the proposed safest limit of USEPA (2004) and WHO (2011). In addition, potentiality of As associated cancer risk should be a concern as the TCR for this metal(oid) is close to the safety limit. From both categories, children are found in a more vulnerable state according to the health risk estimation of every metal(oid)s.

\section{Conclusions}

This study assessed the tap water quality of Dhaka city based on the concentration of dissolved metal(oid)s (Cr, $\mathrm{Mn}, \mathrm{Fe}, \mathrm{Co}, \mathrm{Ni}, \mathrm{Cu}, \mathrm{Zn}, \mathrm{As}, \mathrm{Cd}, \mathrm{Hg}$, and $\mathrm{Pb}$ ) and estimated the potential health risks of the city dwellers. The measured elemental concentrations were within the permissible limit, except $\mathrm{Fe}, \mathrm{Cr}$, and $\mathrm{Pb}$. Besides, based on elemental abundances, distributions, and entropy water quality index ranking, sample water of eight different locations including W-7 (Kafrul), W-14 (Khilgaon), W-18 (Lalbagh), W-21 (Jatrabari), W-24 (Kotwali), W-27 (Badda), W-32 (Shankar), and W-33 (Goran) were identified as immensely contaminated and unsuitable for drinking. Hence, the population of these areas was highly amenable to metal-inducing health hazards. On top of that, except above-mentioned sampling points, the remaining water samples were obtained compatible for use in the household, especially for drinking purposes. The statistical analysis revealed that pollution sources could be mainly attributed to anthropogenic activities and pipeline complications; promoted by domestic sewage and industrial effluents dispensed from conventional wastewater treatment plants and sludge disposal, improper landfilling; and corrosion of pipes respectively. The total target hazard quotient suggested that children are more vulnerable compare to adults. The estimated non-carcinogenic health risks associated with oral and dermal exposures of $\mathrm{Co}$, and carcinogenic health risks related to ingestion of $\mathrm{Pb}$ surpassed the acceptable limits. Overall, tap water of Dhaka City is contaminated with several trace elements and may impose non-carcinogenic and carcinogenic health risks for the city dwellers. Therefore, regular health check-ups are recommended to ensure healthy lives as regular metal(oid)s consumption 
513 could have a chronic impact due to their bioaccumulation over time. Most importantly, children

514 should be under adequate supervision for minimization of probable health risks. In addition, Dhaka

515 Water Supply and Sewerage Authority (WASA) should constantly monitor the tap water quality

516 in relation to metal(oid)s concentration before and after the distribution due to the pipeline

517 corrosivity. Installing advanced water treatment plants to purify the surface water can reduce the

518 dependency on groundwater for sustainable water supply and management. Circumstantially, this

519 study recommended that the regulatory acts and other associated laws should be implemented

520 appropriately to lessen anthropogenic activities and to secure a sustainable water supply and

521 management scheme for the salubrious lives in Bangladesh.

522

\section{Acknowledgement}

524 The authors also deeply acknowledge the individuals, who were kindly associated with the 525 tap-water sampling.

526

527 Funding

528 The authors extend their appreciation to the Deanship of Scientific Research at King Khalid 529 University for funding this work through General Research Project under grant number (GRP-88530 42).

531

532 Conflicts of interest/Competing interests

533 The authors declare that they have no known competing financial interests or personal 534 relationships that could have appeared to influence the work reported in this paper.

535

536 Availability of data and material The manuscript has data included as supplementary material. 537

Code availability Not applicable

\section{Authors' contributions}

Sabiha Hossain and Amit Hasan Anik: Methodology, Investigation, sample collections and

542 preparation. Rahat Khan: Conceptualization, Methodology, Validation, Writing - original draft preparation, Writing - reviewing and editing, Supervision. Farah Tasneem Ahmed and Md. Abu 
Bakar Siddique: Sample analysis, data curation and interpretation. Abdul Hadi Al Nafi Khan, Narottam Saha and Abubakr M. Idris: Original draft preparation, reviewing and editing. Mahbub Alam: Reviewing, editing and supervision. All authors read and approved the final manuscript.

\section{Ethics approval Not applicable}

Consent to participate Not applicable

Consent for publication Not applicable

\section{References}

Abdeldayem, R., 2019. A preliminary study of heavy metals pollution risk in water. Applied Water Science, 10(1). https://doi.org/10.1007/s13201-019-1058-X

Abdi, H., and Williams, L.J., 2010. Principal component analysis. Wiley Interdisciplinary Reviews: Computational Statistics, 2(4), 433-459. https://doi.org/10.1002/wics.101

Abeer, N., Khan, S., Muhammad, S., Rasool, A., Ahmad, I., 2020. Health risk assessment and provenance of arsenic and heavy metal in drinking water in Islamabad, Pakistan. $\begin{array}{lllll}\text { Environmental Technology \& Innovation, } & 20, & 101171 .\end{array}$ https://doi.org/10.1016/j.eti.2020.101171

Adel, M., Dadar, M., Fakhri, Y., Oliveri Conti, G., Ferrante, M., 2016. Heavy metal concentration in muscle of pike (Esox luciusLinnaeus, 1758) from Anzali international wetland, southwest of the Caspian Sea and their consumption risk assessment. Toxin Reviews, 35(34), 217-223. https://doi.org/10.1080/15569543.2016.1223694

Ahmed, F.T., Khan, A.H.N., Khan, R., Saha, S.K., Alam, M.F., Dafader, N.C., 2021. Characterization of arsenic contaminated groundwater from central Bangladesh: Irrigation feasibility and preliminary health risks assessment. Environmental Nanotechnology, Monitoring \& Management. https://doi.org/10.1016/j.enmm.2021.100433

Ahsan, M.A., Satter, F., Siddique, M.A.B., Akbor, M.A., Shamim, A., Shajahan, M., Khan, R., 2019. Chemical and physicochemical characterization of effluents from the tanning and textile industries in Bangladesh with multivariate statistical approach. Environ. Monit. Assess. doi:10.1007/s10661-019-7654-2.

Aradhi, K.K., Satyanarayanan, M., Pradip, K.G., 2009. Assessment of heavy metal pollution in water using multivariate statistical techniques in an industrial area: A case study from Patancheru, Medak district, Andhra Pradesh, India. J. Hazard. Mater. 167, 366-373.

Armitage, P., Bowes, M. and Vincent, H., 2007. Long-term changes in macro invertebrate communities of a heavy metal polluted stream: the river Nent (Cumbria, UK) after 28 years. River Research and Applications, 23(9), pp. 997-1015. 
Asaduzzaman, A.T.M., Nury, S.N., Hoque, S., Sultana, S., 2002. Water and soil contamination from tannery waste: Potential impact on public health in Hazaribag and surroundings, Dhaka, Bangladesh. Atlas of Urban Geology, 14, 415-443.

Atapour, H., 2012. Geochemical baseline of major anions and heavy metals in ground waters and drinking waters around the urban areas of Kerman city, southeastern Iran. Environmental Earth Sciences 67, 2063-2076.

Atashi, H., Mansoorkiai, R., Akbari, F., 2009. Cobalt in Zahedan drinking water. Journal of Applied Sciences Research, 5(12), 2203-2207.

BMD, 2016. Bangladesh Meteorological Department. Dhaka, Assessed on June 10, 2019.

Banglapedia, 2018. National Encyclopaedia of Bangladesh (Geology). http://en.banglap edia.org/index.php?titleDhaka. (Accessed 20 December 2020).

Bhuiyan, M.A.H., Suruvi, N.H., Dampare, S.B., Islam, M.A., Quraishi, S.B., Ganyaglo, S., Suzuki, S., 2011. Investigation of the possible sources of heavy metal contamination in lagoon and canal water in the tannery industrial area in Dhaka, Bangladesh. Environ. Monit. Assess. $175,633-649$.

Bhuiyan, M.A.H., Bodrud-Doza, M., Islam, A.R.M.T., Rakib, M.A., Rahman, M.S., Ramanathan, A.L., 2016. Assessment of groundwater quality of Lakshimpur district of Bangladesh using water quality indices, geostatistical methods, and multivariate analysis. Environ. Earth Sci. $75,1020$.

BIS (Bureau of Indian Standards). 1991. Indian Standard for Drinking Water - Specification IS 10500:1991.

Bodrud-Doza, M., Islam, S., Rume, T., Quraishi, S., Rahman, M., Bhuiyan, M., 2020. Groundwater quality and human health risk assessment for safe and sustainable water supply of Dhaka City dwellers in Bangladesh. Groundwater For Sustainable Development, 10, 100374. https://doi.org/10.1016/j.gsd.2020.100374

Bodrud-Doza, M., Bhuiyan, M.A.H., Islam, S.M.D.U., Rahman, M.S., Haque, M.M., Fatema, K.J., Ahmed, N., Rakib, M.A., Rahman, M.A., 2019a. Hydrogeochemical investigation of groundwater in Dhaka City of Bangladesh using GIS and multivariate statistical techniques. Groundwater Sustain. Develop 8, 226-244.

Bodrud-Doza, M., Bhuiyana, M.A.H., Islam, S.M.D.U., Quraishi, S.B., Muhib, M.I., Rakib, M.A., Rahman, M.S., 2019b. Delineation of trace metals contamination in groundwater using geostatistical techniques: a study on Dhaka City of Bangladesh 2019b. Groundwater Sustain. Develop. 9, 100212. https://doi.org/10.1016/j. gsd.2019.03.006.

Bodrud-Doza, M., Islam, A.R.M.T., Ahmed, F., Das, S., Saha, N., Rahman, M.S., 2016. Characterization of groundwater quality using water evaluation indices, multivariate statistics and geostatistics in central Bangladesh. Water Sci. 30 (1), 19-40.

Bortey-Sam, N., Nakayama, S.M.M., Ikenaka, Y., Akoto, O., Yohannes, Y.B., Baidoo, E., Mizukawa, H., Ishizuka, M., 2015. Human health risks from metals and metalloid via consumption of food animals near gold mines in Tarkwa, Ghana: estimation of the daily intakes and target hazard quotients (THQs). Ecotoxicol. Environ. Saf. 111, 160-167. 
Britannica, 2019. The Editors of Encyclopaedia. "Dhaka". Encyclopedia Britannica. https://www.britannica.com/place/Dhaka. Accessed 9 July 2021.

Björn, Z., Vergara, J., Dunkelberg, H., 2003. Copper concentrations in tap water and possible effects on infant's health-Results of a study in Lower Saxony, Germany. Environmental research. 92. 129-38. 10.1016/S0013-9351(03)00037-9.

Cartier, C., Nour, S., Richer, B., Deshommes, E., \& Prévost, M., 2012. Impact of water treatment on the contribution of faucets to dissolved and particulate lead release at the tap. Water Research, 46(16), 5205-5216.

Çelebi, A., Şengörür, B., Kløve, B., 2014. Human health risk assessment of dissolved metals in groundwater and surface waters in the Melen watershed, Turkey. Journal of Environmental Science and Health, Part A 49, 153-161.

Dessie, B., Gari, S., Mihret, A., Desta, A., \& Mehari, B., 2021. Determination and health risk assessment of trace elements in the tap water of two Sub-Cities of Addis Ababa, Ethiopia. Heliyon, 7(5), e06988. https://doi.org/10.1016/j.heliyon.2021.e06988

De Miguel, E., Iribarren, I., Chacon, E., Ordonez, A., Charlesworth, S., 2007. Risk based evaluation of the exposure of children to trace elements in playgrounds in Madrid (Spain). Chemosphere 66, 505-513.

Dong, W., Zhang, Y., Quan, X., 2020. Health risk assessment of heavy metals and pesticides: A case study in the main drinking water source in Dalian, China. Chemosphere, 242, 125113. https://doi.org/10.1016/j.chemosphere.2019.125113

DWASA, 2019. Annual Report (2019-2020), Dhaka Water Supply and Sewerage Authority. (DWASA), Dhaka.

DWASA, 2013. Annual Report (2012-2013), Dhaka Water Supply and Sewerage Authority. (DWASA), Dhaka.

ECR (The Environment Conservation Rules). 1997. Government of the People's Republic of Bangladesh, Ministry of Environment and Forest.

Egbueri, J.C., Ezugwu, C.K., Ameh, P.D., Unigwe, C.O., Ayejoto, D.A., 2020. Appraising drinking water quality in Ikem rural area (Nigeria) based on chemometrics and multiple indexical methods. Environmental Monitoring and Assessment, 192, 1-18. https://doi.org/10.1007/s10661-020-08277-3.

EPA (Environmental Protection Agency). 2001. Parameters of water quality. Interpretation and Standards. Published by the Environmental Protection Agency, Ireland.

EU (European Community), 1998. The quality of water intended to human consumption. Directive 1998/83/EC, Official Journal L330/05.12.1998. European Community, pp. 32-54.

Faier, M.C., Dumitrel, G., Perju, D., 2009. Experimental Modeling of Heavy Metals Concentration Distribution in Rivers. Chem. Bull. "POLITEHNICA" Univ. (Timisoara), Volume 56(70).

Fakhri, Y., Saha, N., Ghanbari, S., Rasouli, M., Miri, A., Avazpour, M., Rahimizadeh, A., Riahi, S.M., Ghaderpoori, M., Keramati, H., Moradi, B., 2018a. Carcinogenic and noncarcinogenic health risks of metal (oid) $\mathrm{s}$ in tap water from Ilam city, Iran. Food and chemical toxicology, 118, 204-211. https://doi.org/10.1016/j.fct.2018.04.039 
Fakhri, Y., Mohseni-Bandpei, A., Conti, G.O., Ferrante, M., Cristaldi, A., Jeihooni, A.K., Alinejad, A., Mohseni, S.M., Sarkhosh, M., Keramati, H., 2018b. Systematic review and health risk assessment of arsenic and lead in the fished shrimps from the Persian gulf. Food and Chemical Toxicology. 113, 278-286. https://doi.org/10.1016/j.fct.2018.01.046.

Fakhri, Y., Mohseni-Bandpei, A., Oliveri Conti, G., Keramati, H., Zandsalimi, Y., Amanidaz, N., Hosseini Pouya, R., Moradi, B., Bahmani, Z., Rasouli Amirhajeloo, L., 2017. Health risk assessment induced by chloroform content of drinking water in Iran: systematic review. Toxin Reviews 36: 1-11.

Fang, T., Liu, G., Zhou, C., Sun, R., Chen, J., Wu, D., 2014. Lead in Chinese coals: distribution, modes of occurrence, and environmental effects. Environ. Geochem. Health 36 (3), 563581.

Fagerberg, B., Borné, Y., Barregard, L., Sallsten, G., Forsgard, N., Hedblad, B., Persson, M., Engström, G., 2017. Cadmium exposure is associated with soluble urokinase plasminogen activator receptor, a circulating marker of inflammation and future cardiovascular disease. Environmental Research, 152, 185-191.

Flora, G., Gupta, D., Tiwari, A., 2012. Toxicity of lead: a review with recent updates. Interdiscip Toxicol 5, 47-58.

Frisbie, S.H., Mitchell, E.J., Dustin, H., Maynard, D.M., Sarkar, B., 2012. World health organization discontinues its drinking-water guideline for Manganese. Environ. Health Perspect., 120, 775-778, https://doi.org/10.1289/ehp.1104693.

Gao, B., Gao, L., Gao, J., Xu, D., Wang, Q., Sun, K., 2019. Simultaneous evaluations of occurrence and probabilistic human health risk associated with trace elements in typical drinking water sources from major river basins in China. Sci. Total Environ. 666, 139-146. https://doi.org/10.1016/j.scitotenv.2019.02.148

Gbadamosi, M., Afolabi, T.A., Ogunneye, A.L., Ogunbanjo, O.O., Omotola, E.O., Kadiri, T.M., Akinsipo, O.B., Jegede, D.O., 2018. Distribution of radionuclides and heavy metals in the bituminous sand deposit in Ogun State, Nigeria-A multi-dimensional pollution, health and radiological risk assessment. J. Geochem. Explor. 190, 187-199.

Ghasemidehkordi, B., Malekirad, A.A., Nazem, H., Fazilati, M., Salavati, H., Shariatifar, N., Rezaei, M., Khaneghah, A.M., Fakhri, Y., 2018. Concentration of lead and mercury in collected vegetables and herbs from Markazi province, Iran: Non-carcinogenic risk assessment. Food and Chemical Toxicology. 113, 204-210. https://doi.org/10.1016/j.fct.2018.01.048

Gonzalez, S., Lopez-Roldan, R., \& Cortina, J., 2013. Presence of metals in drinking water distribution networks due to pipe material leaching: a review. Toxicological \& $\begin{array}{lll}\text { Environmental Chemistry, } & \text { 95(6), }\end{array}$ https://doi.org/10.1080/02772248.2013.840372

Gorgij, A.D., Kisi, O., Moghaddam, A.A., Taghipour, A., 2017. Groundwater quality ranking for drinking purposes, using the entropy method and the spatial autocorrelation index. Environ Earth Sic, 76, 269. https://doi.org/10.1007/s12665-0176589-6

Guey-Shin, Sh., Bai-You, Ch., Chi-Ting, Ch., Pei-Hsuan, Y., Tsun-Kuo, Ch., 2011. Applying factor analysis combined with kriging and information entropy theory for mapping and 
evaluating the stability of groundwater quality variation in Taiwan. Int. J. Environ. Res. Public Health 8, 1084-1109.

Habib, M.A., Islam, A.R.M.T., Bodrud-Doza, M., Mukta, F.A., Khan, R., Siddique, M.A.B., Phoungthong, K., Techato, K., 2020. Simultaneous appraisals of pathway and probable health risk associated with trace metals contamination in groundwater from Barapukuria coal basin, Bangladesh. Chemosphere 242, 125183. doi:10.1016/ j.chemosphere.2019.125183.).

Haq, K.A., 2006. Water Management in Dhaka. International Journal of Water Resources Development 22:2: 291-311.

Hasan, A.B., Reza, A.S., Kabir, S., Siddique, M.A.B., Ahsan, M.A. and Akbor, M.A., 2020. Accumulation and distribution of heavy metals in soil and food crops around the ship breaking area in southern Bangladesh and associated health risk assessment. SN Applied Sciences, 2(2), pp.1-18.

Hossain, A.M.M.M., Fien, J., Horne, R., 2018. Megacity Dhaka: 'water security syndrome' and implications for the scholarship of sustainability. Sustain. Water Resour. Manag. 4, 63-78.

Hossain, D., Islam, M.S., Sultana, N., Tusher, T.R., 2015. Assessment of Iron Contamination in Groundwater at Tangail Municipality, Bangladesh. Journal of Environmental Science and Natural Resources 6(1). DOI:10.3329/jesnr.v6i1.22051

Hoque, M.A., Hoque, M.M., Ahmed, K.M., 2007. Declining groundwater level and aquifer dewatering in Dhaka metropolitan area, Bangladesh: causes and quantification. Hydrogeol. J. $15,1523-1534$.

Huang, G., Chen, Z., Liu, F., Sun, J., Wang, J., 2014. Impact of human activity and natural 685 processes on groundwater arsenic in an urbanized area (South China) using multivariate 686 statistical techniques. Environ. Sci. Pollut. Res. 21, 13043-13054.

Ismail, A., Shareef, M. and Alatar, F., 2019. Hydrochemistry of Groundwater and its Suitability for Drinking and Irrigation in Baghdad, Iraq. Environmental Processes, 6(2), pp.543-560.

Islam, A.R.M.T., Islam, H.M.T., Mia, M.U., Khan, R., Habib, M.A., Bodrud-Doza, M., Siddique, M.A.B., Chu, R., 2020. Co-distribution, possible origins, status and potential health risk of trace elements in surface water sources from six major river basin, Bangladesh. Chemosphere. doi:10.1016/j.chemosphere.2020.126180.

Islam, A.T., Shen, S., Haque, M.A., Bodrud-Doza, M., Maw, K.W., Habib, M.A., 2018. Assessing ground water quality and its sustainability in Joypurhat district of Bangladesh using GIS and multivariate statistical approaches. Environment, Development and Sustainability, 20(5), 1935-1959.

Islam, S.M.D., Bhuiyan, M.A.H., Rume, T., Mohinuzzaman, M., 2016. Assessing heavy metal contamination in the bottom sediments of Shitalakhya River, Bangladesh; using pollution evaluation indices and geo-spatial analysis. Pollution 2 (3), 299-312.

Islam, M., Uddin, M., Tareq, S., Shammi, M., Kamal, A., \& Sugano, T., Kurasaki, M., Saito, T., Tanaka, S., Kurmatiz, H., 2015. Alteration of Water Pollution Level with the Seasonal Changes in Mean Daily Discharge in Three Main Rivers around Dhaka City, Bangladesh. Environments, 2(4), 280-294. https://doi.org/10.3390/environments2030280 
Islam, S.M.D., Azam, G., 2015. Seasonal variation of physicochemical and toxic properties in three major rivers; Shitalakhya, Buriganga and Turag around Dhaka city, Bangladesh. $J$. Biodivers. Environ. Sci. (JBES) 7 (3), 120-131.

Khan, R., Das, S., Kabir, S., Habib, M.A., Naher, K., Islam, M.A., Tamim, U., Rahman, A.K.M.R., Deb, A.K., Hossain, S.M., 2019. Evaluation of the elemental distribution in soil samples collected from ship-breaking areas and an adjacent island. Journal of Environmental Chemical Engineering, 7, (https://doi.org/10.1016/j.jece.2019.103189)

Khan, S., Shah, I.A., Muhammad, S., Malik, R.N., Shah, M.T., 2015. Arsenic and heavy metal concentrations in drinking water in Pakistan and risk assessment: a case study. Human and Ecological Risk Assessment: An International Journal 21, 1020-1031.

Kim, J. H., Gibb, H. J., Howe, P. D., Team, W. H. O. C. S., \& Safety, I. P. on C., 2006. Cobalt and inorganic cobalt compounds / prepared by James H. Kim, Herman J. Gibb, Paul D. Howe. World Health Organization. https://apps.who.int/iris/handle/10665/43426

Krishna, A.K., Mohan, K.R., 2014. Risk assessment of heavy metals and their source distribution in waters of a contaminated industrial site. Environ. Sci. Pollut. Res. 21, 3653-3669.

Kumar, M., Nagdev, R., Tripathi, R., Singh, V., Ranjan, P., Soheb, M., Ramanathan, A., 2019. Geospatial and multivariate analysis of trace metals in tubewell water using for drinking purpose in the upper Gangetic basin, India: Heavy metal pollution index. Groundwater For Sustainable Development, 8, 122-133. https://doi.org/10.1016/j.gsd.2018.10.00136533669.

Lattin, J., Carrol, D., Green, P., 2003. Analyzing Multivariate Data. Duxbury Press, Belmont.

Le Bot, B., Lucas, J., Lacroix, F., Glorennec, P., 2016. Exposure of children to metals via tap water ingestion at home: Contamination and exposure data from a nationwide survey in France. Environment International, 94, 500-507. https://doi.org/10.1016/j.envint.2016.06.009

Liu, X., Song, Q., Tang, Y., Li, W., Xu, J., Wu, J., Wang, F., Brookes, P.C., 2013. Human health risk assessment of heavy metals in soil-vegetable system: a multi-medium analysis. Science of the Total Environment 463, 530-540.

Malakootian, M., Mobini, M., Sharife, I., 2014. Evaluation of Corrosion and Scaling Potential of Wells Drinking Water and Aqueducts in Rural Areas Adjacent to Rafsanjan Fault in During October to December 2013. Journal of Rafsanjan University of Medical Sciences 13, 293304.

Maw, A.M., Phyu, K.P., Aung, M.N., Mar, K.K., Khin, S.O., Khaing, K.K., Thura, A., THU, A., Zin, P.W., Thin, K.M., Thant, K.Z., 2020. Approach to assessment of heavy metals contamination in drinking water, Mandalay region, Myanmar. IOP Conference Series: Earth And Environmental Science, 496, 012008. https://doi.org/10.1088/1755$1315 / 496 / 1 / 012008$

Martin, S., Griswold, W., 2009. Human health eff ects of heavy metals. Environmental Science and Technology Briefs for Citizens(15): 1-6.

Matsumoto, S.T., Mantovani, M.S., Malaguttii, M.I.A., Dias, A.L., Fonseca, I.C., Marin-Morales M.A., 2006. Genotoxicity and mutagenicity of water contaminated with tannery effluents, 
as evaluated by the micronucleus test and comet assay using the fish Oreochromis niloticus and chromosome aberrations in onion root-tips. Genet Mol Bio, 129(1): $148-158$.

McNeill, L.S., Edwards, M., 2001. Iron pipe corrosion in distribution systems. Journal - American Water Works Association 93(7):88-100. DOI:10.1002/j.1551-8833.2001.tb09246.x

Momot, O., Synzynys, B., 2005. Toxic Aluminium and Heavy Metals in Groundwater of Middle Russia: Health Risk Assessment. International Journal Of Environmental Research And Public Health, 2(2), 214-218. https://doi.org/10.3390/ijerph2005020003

Morais, S., Costa, F.G., Pereira, M.L., 2012. Heavy metals and human health, in Environmental health - emerging issues and practice (Oosthuizen J ed). InTech. pp. 227-246.

Mohammadi, A.A., Zarei,A., Majidi, S., Ghaderpouri, A., Hashempour, Y., Ghaderpoori, M. 2019. Carcinogenic and non-carcinogenic health risks assessment of heavy metals in drinking water of Khorramabad, Iran.MethosX,6: 1642-1651.

Muhammad, S., Shah, M., Khan, S., 2011. Health risk assessment of heavy metals and their source apportionment in drinking water of Kohistan region, northern Pakistan. Microchemical Journal, 98(2), 334-343. https://doi.org/10.1016/j.microc.2011.03.003.

Nguyen, B.T., Nguyen, T.M.T., Bach, Q.V., 2020. Assessment of groundwater quality based on principal component analysis and pollution source-based examination: a case study in Ho Chi Minh City, Vietnam. Environmental Monitoring and Assessment, 192(6), 395-395.

O'Brien, T., Xu, J., Patierno, S.R., 2001. Effects of glutathione on chromium-in-duced DNA crosslinking and DNA polymerase arrest. In Molecular Mecha-nisms of Metal Toxicity and Carcinogenesis (pp. 173-182). Springer US.

Opoku, P., Anornu, G., Gibrilla, A., Owusu-Ansah, E., Ganyaglo, S., Egbi, C., 2020. Spatial distributions and probabilistic risk assessment of exposure to heavy metals in groundwater in a peri-urban settlement: case study of Atonsu-Kumasi, Ghana. Groundwater For Sustainable Development, 10, 100327. https://doi.org/10.1016/j.gsd.2019.100327

Paustenbach, D.J., Finley, B.L., Mowat, F.S., Kerger, B.D., 2003. Human health risk and exposure assessment of chromium (VI) in tap water. J Toxicol Environ Health A. 66(14):1295-339. doi: 10.1080/15287390306388. PMID: 12851114.

Pei-Yue, L., Hui, Q., Jian-Hua, W., 2010. Groundwater quality assessment based on improved water quality index in Pengyang plain, Ningxia, northwest China. E-J Chem. 7(S1), S209S216.

Peng, C., Hill, A., Friedman, M., Valentine, R., Larson, G., \& Romero, A. et al., 2012. Occurrence of trace inorganic contaminants in drinking water distribution systems. Journal - American Water Works Association, 104(3), E181-E193. https://doi.org/10.5942/jawwa.2012.104.0042

Qiao, J., Zhu, Y., Jia, X., Shao, M., Niu, X., Liu, J., 2020. Distributions of arsenic and other heavy metals, and health risk assessments for groundwater in the Guanzhong Plain region of China. Environmental Research, 108957. https://doi.org/10.1016/j.envres.2019.108957 
Qu, L., Huang, H., Xia, F., Liu, Y., Dahlgren, R.A., Zhang, M., Mei, K., 2018. Risk analysis of heavy metal concentration in surface waters across the rural-urban interface of the WenRui Tang River, China. Environmental Pollution. 237, 639-649.

Rahman, A.T.M., Paul, M., Bhoumik, N., Hassan, M., Alam, M. K., Aktar, Z., 2020. Heavy metal pollution assessment in the groundwater of the Meghna Ghat industrial area, Bangladesh, by using water pollution indices approach. Applied Water Science, 10:186 https://doi.org/10.1007/s13201-020-01266-4.

Rahman, M. M., Asaduzzaman, M., Naidu, R., 2013. Consumption of arsenic and other elements from vegetables and drinking water from anarsenic-contaminated area of Bangladesh. J. Hazard. Mater. 262, 1056-1063.

Rahman, M.S., Molla, A.H., Saha, N., Rahman, A., 2012. Study on heavy metals levels and its risk assessment in some edible fishes from Bangshi River, Savar, Dhaka, Bangladesh. Food Chemistry 134, 1847-1854.

Rodriguez-Proteau, R., Grant, R.L., 2005. Toxicity evaluation and human health risk assessment of surface and ground water contaminated by recycled hazardous waste materials. In Water Pollution (pp. 133-189). Springer, Berlin, Heidelberg.

Sabrina, M., Hasan,A.M., Omor, F.M., Subhagata, C., 2013. Analysis of WASA Supplied Drinking Water Around Dhaka City from Laboratory Analysis Perspective. International Journal of Chemical and Physical Sciences. Vol. 2, No. 6, ISSN: 2319-6602.

Saha, S., Reza, A.H.M.S., Roy, M. K., 2019. Hydrochemical evaluation of groundwater quality of the Tista floodplain, Rangpur, Bangladesh. Appl. Water Sci.9, 198. doi:10.1007/s13201019-1085-7.

Saha, N., Rahman, M.S., Ahmed, M.B., Zhou, J.L., Ngo, H.H., Guo, W., 2017. Industrial metal pollution in water and probabilistic assessment of human health risk. J. Environ. Manag. $185,70-78$.

Saha, N., Zaman, M., 2013. Evaluation of possible health risks of heavy metals byconsumption of foodstuffs available in the central market of Rajshahi City, Bangladesh. Environmental monitoring and assessment 185, 3867-3878.

SCHER (Scientific Committee Health and Environmental Risks). 2015. ISSN: 1831-4775. DOI: 10.2772/41993.http://ec.europa.eu/health/scientific_committees/environmental_risks/opin ions/ index_en.htm.

Schwenk, W., 1991. Nickel migration from $\mathrm{Cr}-\mathrm{Ni}$ stainless steel exposed to potable water, British Corrosion Journal, 26:4, 245-249, DOI: 10.1179/000705991798268973

Shannon, C.E., (1948). A mathematical theory of communication. Bell Syst Tech J 27(379-423), 623-656.

Sharmin, S., Mia, J., Miah, M.S., Zakir, H.M., 2020. Hydrochemistry and heavy metal contamination in groundwaters of Dhaka metropolitan city, Bangladesh: Assessment of human health impact. HydroResearch. 3:106-117.

Shanbehzadeh, S.,Vahid Dastjerdi, M., Hassanzadeh, A., Kiyanizadeh, T., 2014. Heavy metals in water and sediment: a case study of Tembi River. Journal of environmental and public health. https://doi.org/10.1155/2014/858720 
Siddique, M.A.B., Khan, R., Islam, A.R.M.T., Alam, M.K., Islam, M.S., Hossain, M.S., Habib, M.A., Akbor, M.A., Bithi, U.H., Rashid, M.B., Hossain, F., Rahman, I.M.M., Elius, I.B., Islam, M.S., 2021. Quality assessment of freshwaters from a coastal city of southern Bangladesh: Irrigation feasibility and preliminary health risks appraisal, Environmental Nanotechnology, Monitoring \& Management, Volume 16, 100524, ISSN 2215-1532, https://doi.org/10.1016/j.enmm.2021.100524.

Siddique, M.A.B., Alam, M.K., Islam, S., Diganta, M.T.M., Akbor, M.A., Bithi, U.H., Chowdhury, A.I. and Ullah, A.K.M.A., 2020. Apportionment of some chemical elements in soils around the coal mining area in northern Bangladesh and associated health risk assessment. Environmental Nanotechnology, Monitoring \& Management, 14, p.100366.

Singh, R., Gautam, N., Mishra, A., Gupta, R., 2011. Heavy metals and living systems: An overview. Indian J. Pharmacol. 43, 246.

Sun, H., Brocato, J., Costa, M., 2015. Oral Chromium Exposure and Toxicity. Curr Envir Health Rpt 2, 295-303. https://doi.org/10.1007/s40572-015-0054-Z

Szuster-Janiaczyk, A., Zeuschner, P., Noga, P., Skrzypczak, M., 2018. Monitoring of heavy metals in selected Water Supply Systems in Poland, in relation to current regulations. E3S Web Of Conferences, 30, 01017. https://doi.org/10.1051/e3sconf/20183001017

Tamim U., Khan R., Jolly Y.N., Fatema K., Das S., Naher K., Islam M.A., Islam S.M.A., Hossain S.M., 2016. Elemental distribution of metals in urban river sediments near an industrial effluent $\quad$ source. $\quad$ Chemospher $509-518$. https://doi.org/10.1016/j.chemosphere.2016.04.099.

Tatsi, K., Turner, A., Handy, R.D., Shaw, B.J., 2015. The acute toxicity of thallium to freshwater organisms: implications for risk assessment. Sci. Total Environ. 536, 382-390.

Tumolo, M., Ancona, V., Paola, D.D., Losacco, D., Campanale, C., Massarelli, C., Uricchio, V. F., 2020. Chromium Pollution in European Water, Sources, Health Risk, and Remediation Strategies: An Overview. Int J Environ Res Public Health. 17(15): 5438.

UN Water, United Nation. 2018. Sustainable Development Goal 6 (SDG-6), Synthesis Report on Water and Sanitation. (Accessed 21 May, 2021) https://sustainabledevelopment.un.org/content/documents/19901SDG6_SR2018_web_3.

United Nations (UN), 2016. The World's Cities in 2016. Report. United Nations, p. 11. Assessed from. http://www.un.org/en/development/desa/population/publications/ pdf/urbanization/the_worlds_cities_in_2016_data_booklet.pdf

UNICEF, 2009. Bangladesh National Drinking Water Quality Survey. Bangladesh Bureau of Statistics, Planning Division, Ministry of Planning, Government of the People's Republic of Bangladesh. https://washdata.org/sites/default/files/documents/reports/Bangladesh2009-MICS-water-quality-report

USEPA, 2004. US Environmental Protection Agency. Risk assessment guidance for superfund volume I: human health evaluation manual (part E, supplemental guidance for dermal risk assessment) fnal. EPA/540/R/99/005 OSWER 9285.702EP PB99-963312 July 2004, Offce of Super fund Remediation and Technology Innovation. 
U.S. Environmental Protection Agency (U.S. EPA), 2004. Estimated per capita water ingestion and body weight in the United States -an update. 312-314.

USEPA, 2009. National Primary and Secondary Drinking Water Standards. U.S. Environmental Protection Agency. Assessed from. http://www.epa.gov/safewater/c onsumer/pdf/mcl.pdf

USEPA, 2011. US Environmental Protection Agency's Integrated Risk Information System. USEPA, IRIS.

Verma, R.K., Sankhla, M.S., and Kumar, R., 2018. Mercury Contamination in Water \& Its Impact on Public Health. International Journal of Forensic ScienceVolume 1, Number 2, July December.

Wagh, V.M., Panaskar, D.B., Mukate, S.V., Gaikwad, S.K., Muley, A.A., Varade, A.M., 2018. Health risk assessment of heavy metal contamination in groundwater of Kadava River Basin, Nashik, India. Modeling Earth Systems and Environment 4, 969-980.

Wang, J., Liu, G.J., Liu, H.Q., Lam, P.K.S., 2017. Multivariate statistical evaluation ofdissolved trace elements and a water quality assessment in the middle reachesof Huaihe River, Anhui, China. Sci. Total Environ. 583, 421-431.

Wendland, F., Hannappel, S., Kunkel, R., Schenk, R., Voigt, H., \& Wolter, R., 2005. A procedure to define natural groundwater conditions of groundwater bodies in Germany. Water Science And Technology, 51(3-4), 249-257. https://doi.org/10.2166/wst.2005.0598

Wu, B., Zhao, D. Y., Jia, H. Y., Zhang, Y., Zhang, X. X., Cheng, S.P., 2009. Preliminary Risk Assessment of Trace Metal Pollutionin Surface Water from Yangtze River in Nanjing Section, China. Bull Environ Contam Toxicol. 82, 405-409. DOI 10.1007/s00128-0089497-3.

WHO, 2004. Fluoride in Drinking Water. Assessed from. https://www.who.int/wate r_sanitation_health/dwq/chemicals/fluoride.pdf

WHO, 2005. Nickel in Drinking-water. https://www.who.int/water sanitation health/gdwqrevision/nickel.

WHO, 2011. WHO Guidelines for Drinking-Water Quality, fourth ed. World Health Organization, Geneva.

Xiao, J., Wang, L., Deng, L., Jin, Z., 2019. Characteristics, sources, water quality and health risk assessment of trace elements in river water and well water in the Chinese Loess Plateau. Sci. Total Environ.,650, 2004-2012.

Yeazdani, S.M.G., 2016. State of drinking water and its management aspects in Dhaka city. Journal of Nepal Geological Society, Vol. 50, pp. 59-64.

Yuan, G., Liu, C., Chen, L., Yang, Z., 2011. Inputting history of heavy metals into the inland lake recorded in sediment profiles: Poyang Lake in China. Journal of Hazardous Materials, 185(1), 336-345. https://doi.org/10.1016/j.jhazmat.2010.09.039

Zakir, H.M., Sharmin, S., Akter, A., Rahman, M.S., 2020. Assessment of health risk of heavy metals and water quality indices for irrigation and drinking suitability of waters: a case study of Jamalpur Sadar area, Bangladesh. Environmental Advances, 2:100005. 
943 Zeng, X.X., Liu, Y.G., You, S.H., Zeng, G.M., Tan, X.F., Hu, X.J., Hu, X., Huang, L., Li, F., 2015. 944 Spatial distribution, health risk assessment and statistical source identification of the trace

945

946 elements in surface water from the Xiangjiang River, China. Environ. Sci. Pollut. Res. 22, 9400-9412.

947 Zhitkovich, A., 2011. Chemical Research in Toxicology. 24 (10), 1617-1629 DOI: $948 \quad 10.1021 / \mathrm{tx} 200251 \mathrm{t}$ 


\section{Figures}

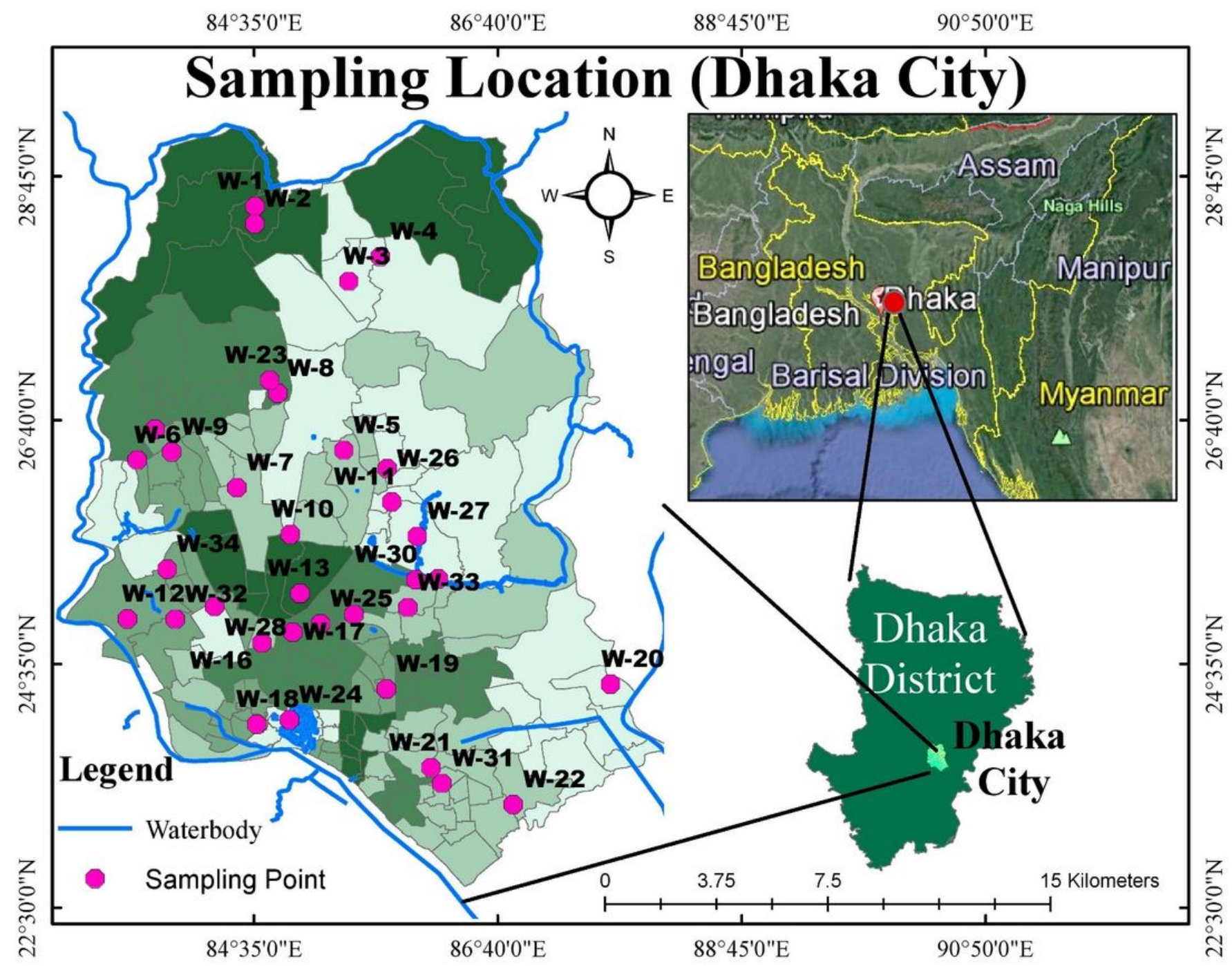

Figure 1

Study area including sampling locations (Dhaka city, Bangladesh). 


\section{Compraison of measured metal(oid)s concentration with national/international recommended value}

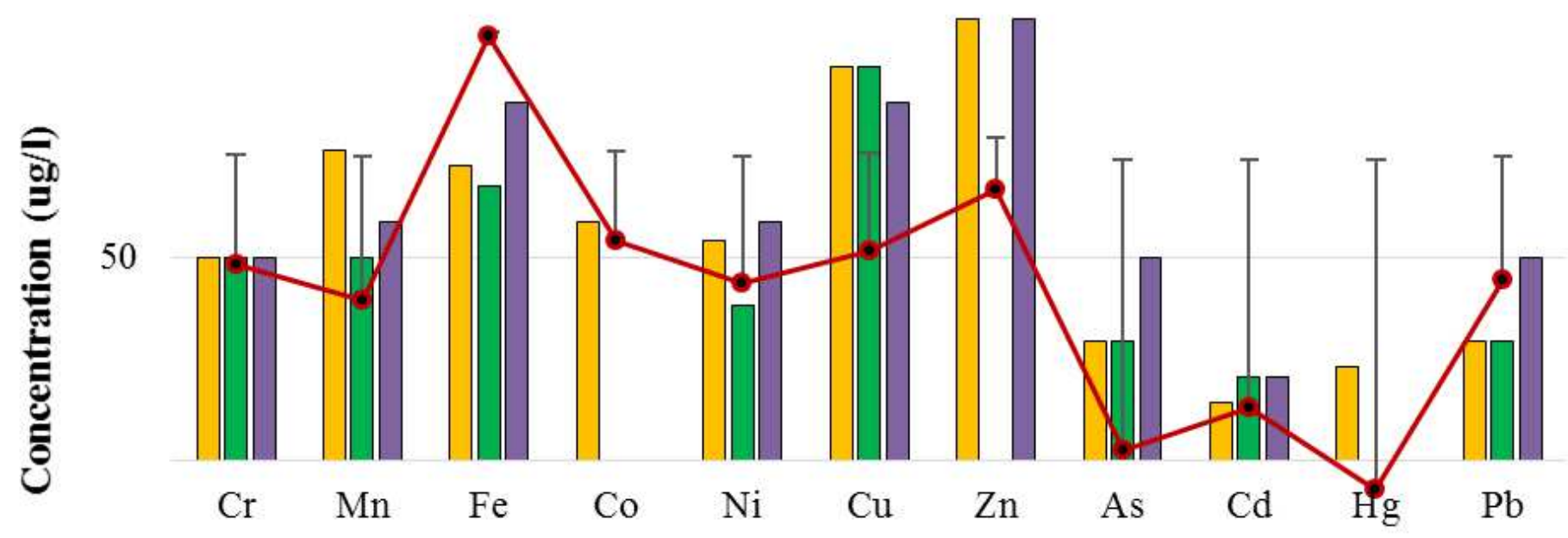

0.1

Trace metal(oid)s

Figure 2

Comparison of measured metal(oid)s concentrations with national/international recommended values.
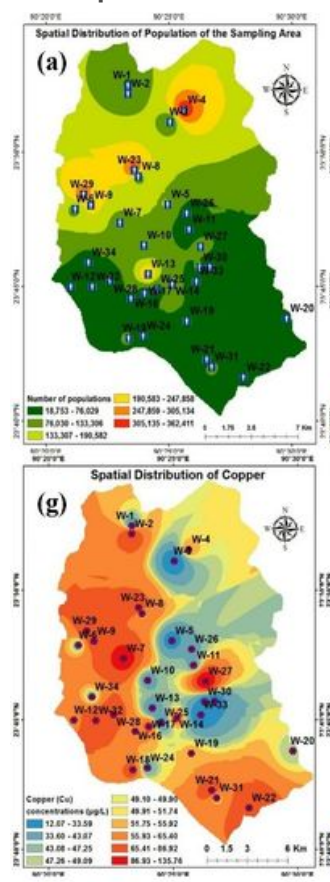

(b)

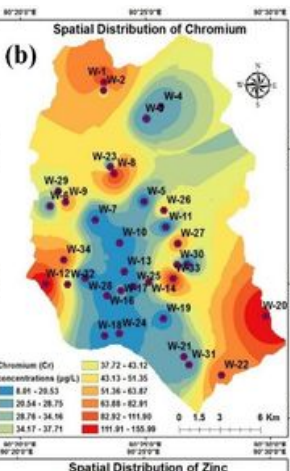

(h)

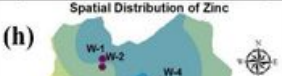

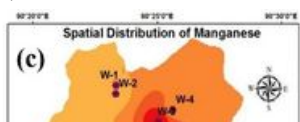
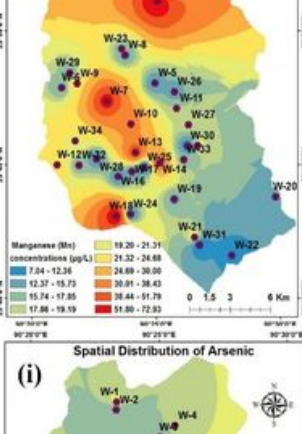

(i)

(j)

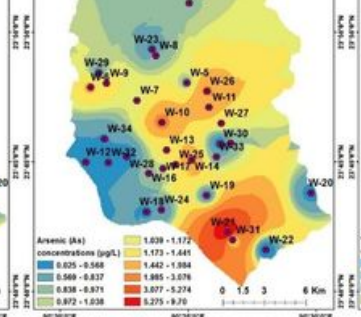

(d) Spatial Distribution of Iron
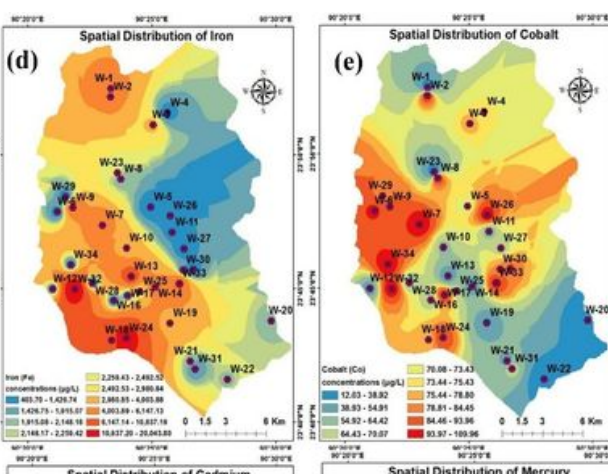

(k)
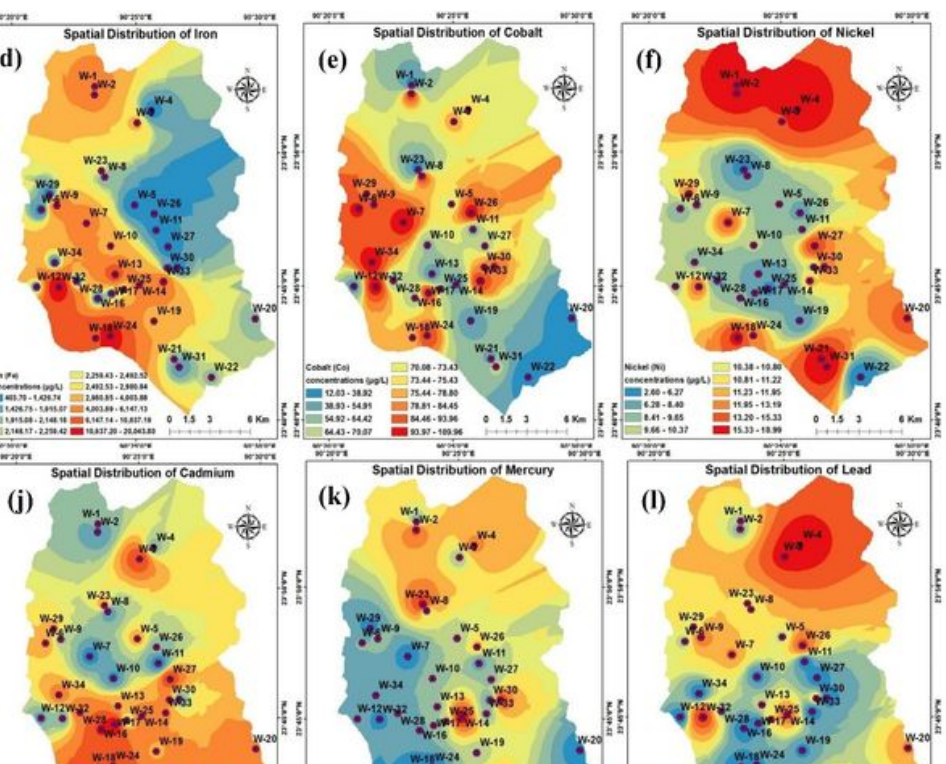

(I)

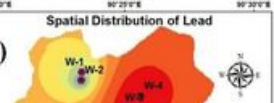

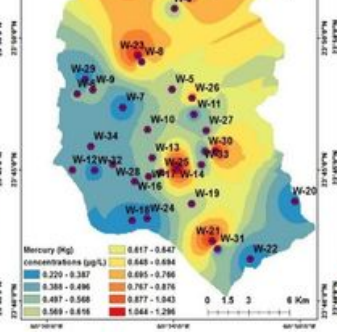
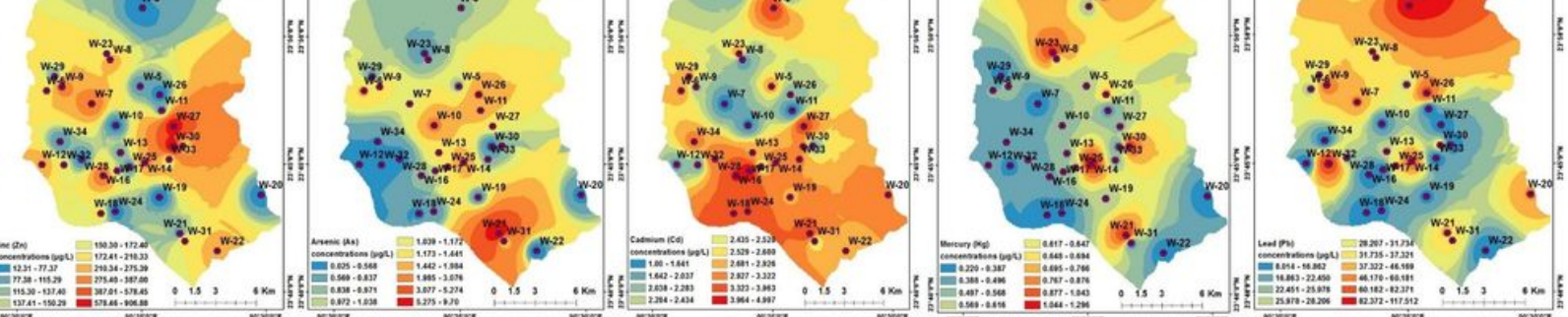

Figure 3 
Spatial distributions of elemental abundances in tap-water of different sampling location along with the population distribution
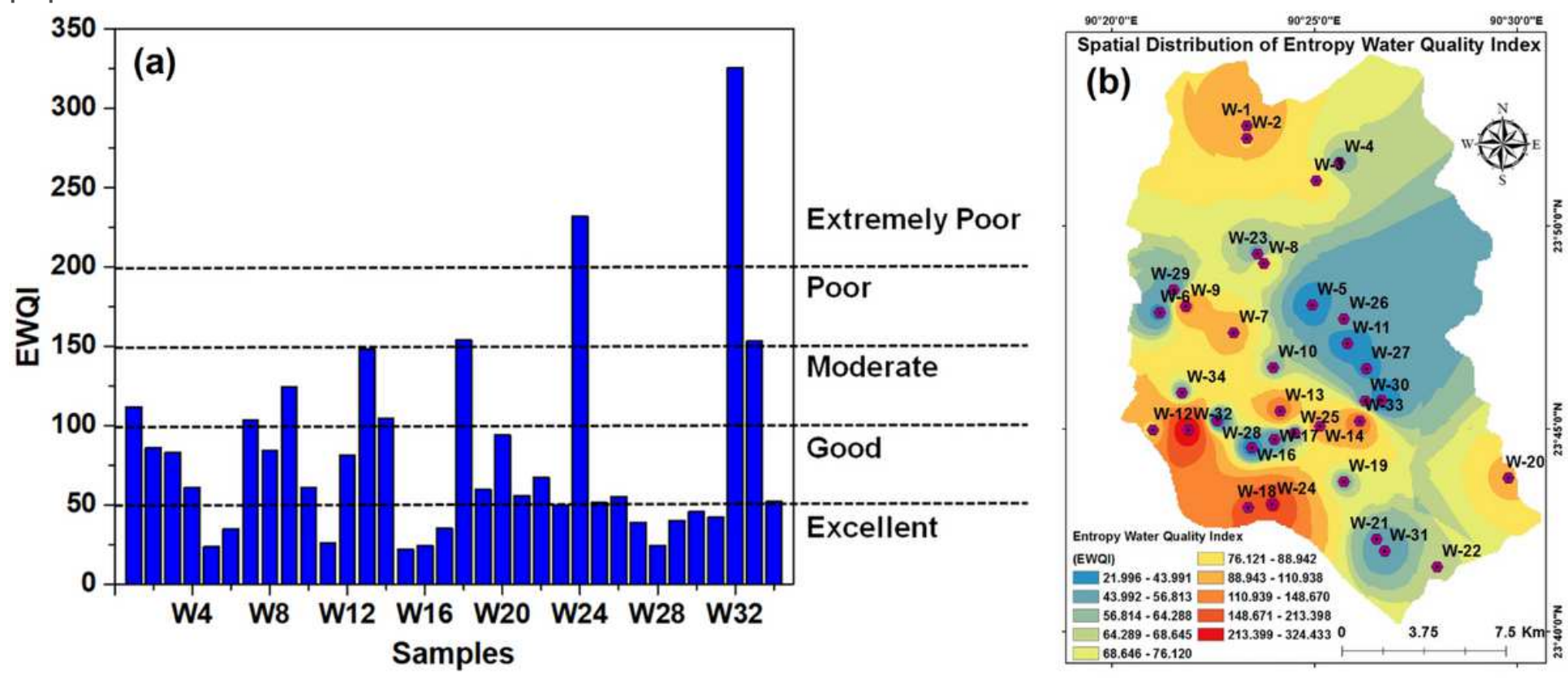

Figure 4

Water quality assessment of the studied area through entropy water quality index (EWQI).
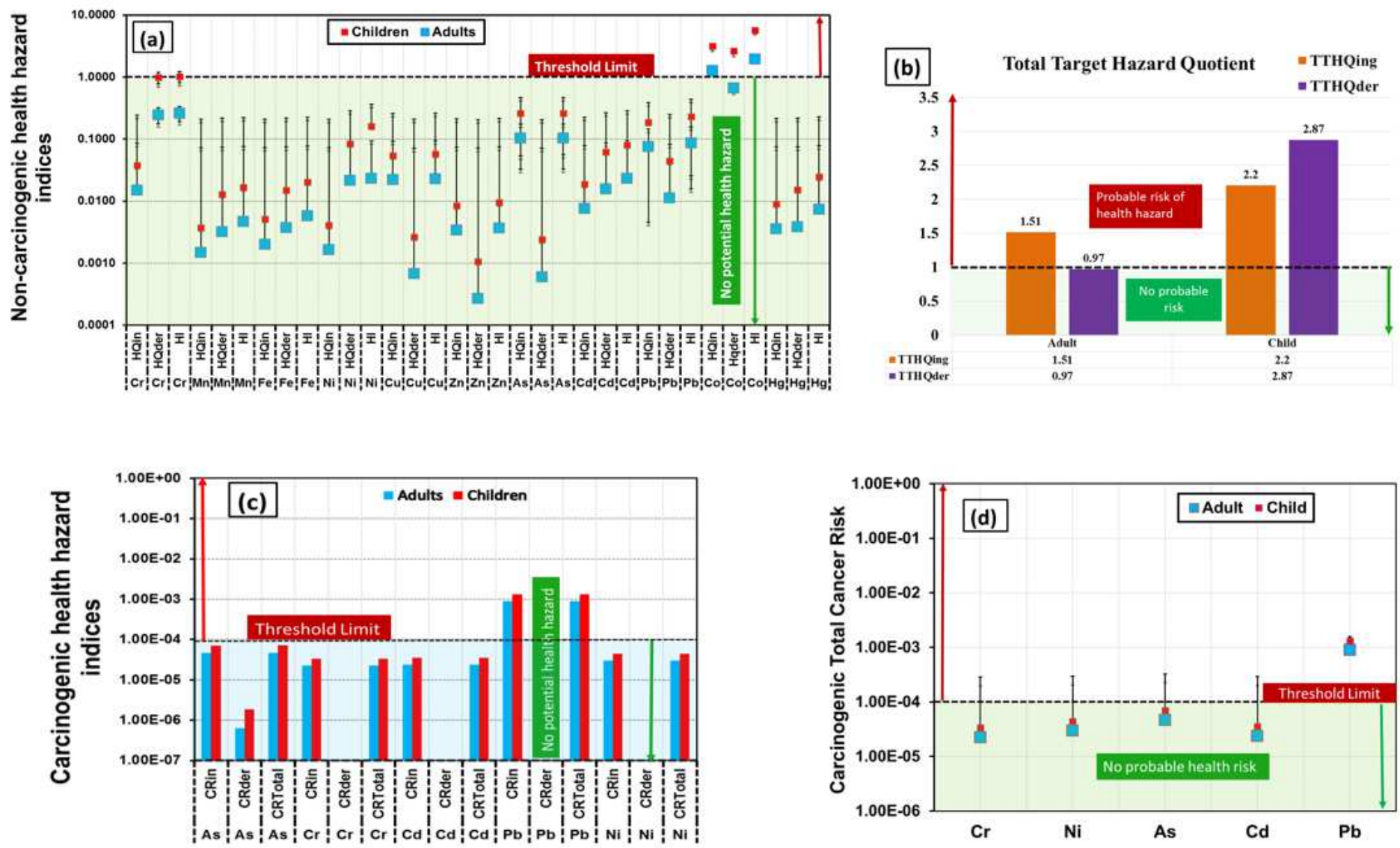

Figure 5 
Estimated health risks indices for the tapwater from Dhaka city (Bangladesh). Non-carcinogenic: (a) health hazard indices and (b) total target hazard quotient (TTHQ); Carcinogenic: (c) health hazard indices and (d) total carcinogenic risk estimation through ingestion and dermal exposure from the elements dissolved in tap-water for children and adults.

\section{Supplementary Files}

This is a list of supplementary files associated with this preprint. Click to download.

- Supplementary.docx 